\title{
ESSAY
}

\section{THE NEW MORALIZERS: TRANSFORMING THE CONSERVATIVE LEGAL AGENDA}

\author{
David A. Super*
}

The essential elements of a wide range of social policies can be described in terms of responses to three basic questions. First, what burdens must the innocent carry? Second, what burdens must the blameworthy bear? And third, how does society assess blame? This Essay examines the increasingly successful efforts of a faction of social conservatives, called here the new moralizers, to reshape the resolution of each of these three issues and with them a wide range of social policies.

Although the relative importance of these three questions has varied over time, the twentieth century saw a movement away from costly individualized adjudications of fault and toward efficiency as a guiding principle of lawmaking. Over the past decade, the new moralizers have sought to reverse this trend selectively, transforming law and social policy to increase reliance on individual assessments of virtue in place of rules of broad application. The new moralizers have imposed a range of per se rules that stigmatize and restrict unpopular groups without individualized findings of fault, while requiring individualized determinations of blameworthiness before restricting members of elites. Most remarkably, they have sought to create conditions in which providing less protection to the concededly innocent appears a moral imperative.

The new moralizers' implicit assumptions about human nature are strikingly inconsistent with those of the law and economics movement, but they have received inadvertent aid from liberals. This Essay concludes that technical arguments cannot meet this agenda's considerable populist appeal. Its excesses, however, can be exposed and contained.

\section{TABle of Contents}

INTRODUCTION ................................... 2034

I. The Roles of Moral and Pragmatic Concerns in

Shaping Law and Social. Policy ................ 2036

A. Three Basic Questions that Define Social Policy ..... 2036

* Associate Professor, University of Maryland Law School. The author is grateful to Harlan Beckley, Richard Boldt, Gene Burns, Stacy Dean, Helen Hershkoff, Stan Katz, Joan Shaughnessy, Susannah Torpey, and Brad Wendel for their helpful comments on earlier versions of this Essay and above all to his dear friend and mentor, the late Marvin Becker, without whose advice and encouragement this Essay would never have been completed. The research of Melanie Coleman, Meri Triades, and Sue McCarty contributed greatly to this Essay. This Essay benefited enormously from the expert editorial guidance of Cynthia Mendez and her colleagues at the Columbia Law Review. The author is grateful to the Frances Lewis Law Center and to the University of Maryland Law School for their generous support of this research. 
B. The Limitations on Moral Arguments in Policy

Debates................................. 2040

1. Preferences for Stability. .................. 2040

2. Reactions to Overreaching................ 2041

3. Shifting Priorities of Elites. ............... 2042

4. The Cost and 1nefficiency of 1ndividualized Determinations of Fault. ................... 2043

C. The lnadequacy of Technical Responses to Moral Arguments.............................. 2045

11. The New Moralizers' Manipulation of Moral Tests in Public Policy ............................... 2048

A. Transforming the Tests of Moral Blameworthiness .... 2050

1. Scrutinizing Existing Behavior. ............... 2051

a. Determining Immorality with Arbitrary Per Se Rules............................. 2053

b. Straddling the Line Between Adjudications of Fault and Legislative Classifications. ........ 2056

c. Imposing Per Se Morality Tests in Private Law. ................................ 2057

2. Restructuring Value-Neutral Legal Systems to Impose New Tests of Moral Virtue. ........... 2058

3. Replacing Broad Rules Regulating Elites with Tests of Moral Culpability. .................... 2065

a. Applications of the New Moralizing to Trusted Elites............................ 2066

b. The Assumptions Underlying the New Moralizers' Treatment of Problematic Behavior by Members of Elite Groups. ............ 2069

B. Harsher Measures Against Those Deemed Unworthy. . 2072

C. Deflecting Appeals to Alleviate the Suffering of the Blameless ............................... 2075

1. Defenses Against Liberal Moral Arguments....... 2076

2. Affirmative Responses to Arguments for Expanding Relief of Innocent Misfortune.

III. The Politics of the New Moralizers ............... 2082

A. Liberals' Inadvertent Aid to the New Moralizers ..... 2083

B. Reconciling the New Moralizers and Economic Conservatives .......................... 2087

C. The Collapse of the Technocratic Middle ......... 2089

D. The Populist Appeal of the New Moralizers......... 2092

E. Responding to the New Moralizers .............. 2093

Conclusion .......................................... 2096 


\section{NTRODUCTION}

Many commentators have noted the stridency of social conservatives' ${ }^{1}$ moralizing in particular public policy areas. Some have seen hypocrisy in various social conservative proposals for government to promote a particular vision of morality after so many years of economic conservatives advocating a limited public sector. Yet each of these debates is a mere symptom of a far broader transformation in the conservative agenda that cuts across a huge swath of social policy. In area after area, an increasingly dominant faction of social conservatives has relied on similar techniques both to blunt liberals' advances and to go on the offensive themselves. The overall contours of this strategy, however, have so far gone largely unanalyzed. At stake is not only the direction of some of the most important areas of law but also control of a conservative movement that for some time had been dominated by the pursuit of laissez faire economics.

This Essay seeks to understand this fundamental change in the role that many conservatives are playing in this country and what it means for the future of law and social policy. To do so, this Essay will identify common themes across a broad range of legal fields. It concludes that this powerful movement threatens to undermine a wide range of social initiatives with broad support among liberals, moderates, and more traditional conservatives. Although by no means antagonistic to the application of moral principles to guide the development of law, this Essay questions the authenticity of some of the judgments of individual character that these new legal rules produce. It also finds a troubling selectivity and sometimes artificiality in this movement's application of moral standards.

It is well beyond the scope of this Essay to assess the merits of the moral premises of these policies, either in context or under any system of ethical philosophy. The moral judgments here are the work of what Judge Posner describes as "moral entrepreneurs,"2 not systematic theorists. For that reason, and because the primary engines of legal change described here are statutory and regulatory rather than judicial, some of

1. Because this Essay is concerned with a political process where the terms "conservative" and "liberal" are applied without a great deal of analytical rigor, superimposing rigorous definitions of these terms would be artificial and even perhaps deceptive. Obviously, some politicians and scholars are conservative in some respects and moderate or liberal in others. And, indeed, some traditional economic conservatives find the social policy prescriptions analyzed in this paper so unpalatable that they would deny those views are conservative at all. Nonetheless, since at least the 1980 election, this country has had a large politically and academically active group that has identified itself as conservative and that forms the dominant core of the Republican Party. The liberal label is less popular and probably has swept in a more eclectic array of beliefs and positions for much longer; it thus is even more resistant to easy definition (apart from, perhaps, "those that oppose conservatives"). Nonetheless, because these labels have meaning to, and are relied upon by, those that make our laws, they are useful benchmarks for this discussion.

2. Richard A. Posner, The Problematics of Moral and Legal Theory, 111 Harv. L. Rev. 1637, 1664-68 (1998) [hereinafter Posner, Problematics]. 
the specific issues of legitimacy and determinacy in contemporary jurisprudential debates do not come to the fore here. ${ }^{3}$

This Essay's thesis is that the movement within American conservatism that gained great power in the 1994 election has sought profound changes in the terms on which public law reconciles moral aspirations and pragmatic concerns. Some broad types of problems that the law had handled pragmatically came to be seen as moral issues, while other, traditionally moral, inquiries were routinized. Perhaps most importantly, this movement has transformed the methods by which the law judges people's morality-and has done so in starkly differing ways for different groups.

In this respect, this movement differs qualitatively from its predecessors over the past several decades. ${ }^{4}$ This new movement not only has brought a new vision of morality into the center of public policy debates but also has sharply changed the extent and nature of the relationship between morality and law. For convenience, this Essay will refer to this movement of social conservatives as the "new moralizers." 5

Part I provides structure to this discussion by identifying three basic questions that shape a wide range of social policies. It then offers a few contrasting examples of the roles that moral arguments have played throughout the history of Anglo American law. These examples demonstrate that commitment to morality as the law's organizing principle has risen and fallen sharply in the past. Accordingly, its current ascendancy should hardly be assumed to be inevitable or permanent. Moreover, society's embrace and rejection of particular types of moral arguments has profoundly shaped the development of many important areas of law. Part I finds that throughout much of the twentieth century the trend was away from relying on costly individualized moral assessments and toward

3. See, e.g., Charles Fried, Philosophy Matters, 111 Harv. L. Rev. 1739, 1743-44 (1998) (arguing that moral reasoning is particularly vital to the role of judges); Anthony $T$. Kronman, The Value of Moral Philosophy, 111 Harv. L. Rev. 1751, 1761-64 (1998) (same).

4. To be sure, moralizing approaches played important roles in some areas of public policy (e.g., public benefits law) long before 1994. Conversely, more traditional economic conservative arguments continue to be central in a number of areas of policy, such as environmental law. The 1994 election nonetheless remains an important watershed. When the conservative-dominated Republican Party seized both houses of Congress and humbled the Democratic President, it obtained the means with which to transform conservative moralism from a convenient tactic in particular areas of law into a hroad strategy for achieving ends that long had eluded economic conservatives.

5. Although housed primarily within the Republican Party, the bounds of this movement are by no means coterminous with that party or with conservatism. Many moderate Republicans and traditional economic conservatives have been coopted to support the new moralizers on an issue-by-issue basis but have by no means embraced the full sweep of that agenda. Conversely, some moderate and conservative Democrats (along with the occasional liberal) have endorsed many parts of this agenda, sometimes even appropriating the new moralizers' methods to try to reshape other areas of social policy. Indeed, President Clinton signed many of the most important new moralizers' initiatives into law. A more precise accounting of the origins of the new moralizers movement, and of the roles of religion and rural America in this transformation of conservatism, is beyond the scope of this Essay. 
simpler, more broadly applicable rules. This allowed the law to be shaped increasingly by economic and technical arguments. Finally, it illustrates the inadequacy of these technical arguments in rebutting wellframed moral ones.

Part II describes the way the new moralizers have transformed much of public law to increase the prevalence and importance of determinations of individual virtue. On each of the three fundamental questions identified in Part I, the new moralizers have seized the agenda and made dramatic gains, both imposing harsher regimes on unpopular groupssuch as welfare recipients, immigrants, debtors, and prisoners-and relaxing government pressure on business managers and other elites. In some instances, their arguments have provided new means of achieving longstanding conservative goals. In others, the new moralizers have transformed the ends as well as the means of the conservative agenda.

Part III then examines the political appeal of the new moralizers. It shows that liberals inadvertently have helped to legitimize this movement. At the same time, economic conservatives have been confronted with a difficult choice as the new moralizers achieve some long-cherished conservative goals but in the process undermine equally well-established tenets of the conservative world view. This Part finds that the new moral arguments have been important in part because their ambiguities allow them to appeal to disparate moderate and conservative factions, seeming to each group to reflect its own views. Part III also finds that the conditions that allowed technical policy arguments to dominate late twentiethcentury law and policy debates have seriously eroded, rendering these arguments increasingly ineffectual. It closes by suggesting how liberals and more traditional, economically oriented conservatives may regain traction by shifting their approaches to each of the three basic questions identified at the beginning of this Essay.

\section{The Roles of Moral and Pragmatic Concerns in Shaping Law and Social Policy}

This Part sketches the landscape that the new moralizers' initiatives have sought to transform. Part 1.A sets out three basic moral questions that, collectively, shape a wide range of social policies. It is these questions to which the new moralizers have sought to offer new kinds of answers. Part I.B offers a highly abbreviated history of the changing roles of these three questions in shaping the law. The new moralizers' approach is remarkable in large part because of its effort to reverse what had appeared to be clear trends developed over several decades. Part I.C then refutes the common assumption that well-informed technical analysis can parry these sorts of moral arguments.

\section{A. Three Basic Questions that Define Social Policy}

The extent of morality's influence on the formation of law may wax and wane considerably over time. Nonetheless, a significant part of why 
people form political institutions is to apply their mores to the world around them. ${ }^{6}$ The details, too, may vary, but the structure of this moral discourse tends to follow familiar patterns. In particular, when society designs policies affecting its members, it ultimately must answer variants of three basic moral questions:

-First, what hardships must the innocent endure?

- Second, what hardships must the blameworthy suffer?

- Third, how does society separate the innocent from the blameworthy? ${ }^{7}$

These questions permeate much of the law. ${ }^{8}$ Answers to these three questions shape public benefit programs. ${ }^{9}$ Answers to these questions

6. See John Rawls, Political Liberalism 176-77 (1993) (theorizing that people in a democratic society draw up a rational plan for the purpose of pursuing their personal conceptions of "the good").

7. To be sure, strenuous debates arise over an array of different issues. Each of those issues, however, tends to be either a reformulation of one or more of these basic questions or a subsidiary issue about how society's answers to the three fundamental questions should be implemented. For example, liberals and conservatives long have divided over how much wealth, if any, society should redistribute from the affluent to the less fortunate or how much equality of wealth it should seek to achieve. To the extent that the unfortunate are assumed to be blameless, this question is substantially identical to the first stated above. If proponents of redistribution believe allocations are appropriate without regard to the character of the beneficiaries, and opponents choose not to inquire into the beneficiaries' behavior, then this debate focuses on the first fundamental question and at least partially eclipses the second and third. If some impoverished people are to be excluded from the redistribution based on their perceived moral faults-criminality, unlawful residence, substance abuse, etc.- then redistributive policy must answer the first and third questions.

Similarly, when a society discriminates against some of its members, it is effectively defining moral fault. If discrimination is based on having willfully committed violence against other members of society, few would quarrel with that definition. If discrimination is based on race, religion, sexual preference, etc., then society can properly be criticized for having answered the third question badly.

8. In traditional common law terms, these three questions translate roughly into what recovery we may obtain on a theory of strict liability, what sort of recovery is only available in the case of fault, and what is the definition of fault. For example, limited restitutionary recoveries may be available without showing the existence of a contract, much less its breach, while only victims of an inexcusable breach of a valid contract may recover the benefit of their bargains. Even if some recovery is available on a strict liability theory in tort, punitive damages typically are reserved for cases of fault. Routine insurance indemnifications are quite different from exemplary damages for bad-faith failure to honor a policy. Because relatively few areas of law require innocent private actors to compensate others for injuries they caused with no possibility of enhanced penalties for proven culpability, private law's focus is overwhelmingly on the rules defining fault.

9. Groups of low-income people have found society generous or harsh depending upon whether they are classified as part of the "worthy poor" or the "unworthy poor." See, e.g., Michael B. Katz, In the Shadow of the Poorhouse 211, 275-80 (I986) (detailing expanding notions of deserving poor during the 1960s and 1970s); Walter 1. Trattner, From Poor Law to Welfare State 58-59, 363 (5th ed. 1994) (pointing out worthy/unworthy poor distinctions in the nineteenth century and during the Reagan administration). The abandonment of efforts to stigmatize the elderly and disabled poor led to the creation of the basically value-neutral Social Security. Similarly, when this country rejected the notion 
also guide many of the regulatory functions of law. ${ }^{10}$ Even in fields where the law seeks to prevent harm to diffuse or indefinite victims, the same basic three questions still apply with regard to the regulatory burdens we impose to prevent that harm. ${ }^{11}$

In theory, one could dispense with the second two questions: Make no attempt to judge individuals' worthiness and thus have no occasion to determine the consequences of unworthiness. As discussed below, this approach has considerable appeal across the political spectrum to those who doubt the reliability of the state's judgments of individuals' worthiness or begrudge the cost of making them. In practice, our legal system has relied upon these judgments so frequently that they are at least occasionally considered in all but a few policy areas. Therefore, although analytically separate, the questions of how unworthiness is determined and how the unworthy are treated are closely linked in practice. In the period between when a criterion for making moral judgments comes under suspicion and when it is rejected outright, reformers commonly seek to capitalize on those doubts to win moderation of the conditions of the dispossessed. On a more individual level, where we have qualms about whether a particular set of circumstances justifies a finding of immorality, we may

that unemployment necessarily signified indolence-when it changed its answer to the third question-unemployment compensation became possible. The provisions of the former Aid to Families with Dependent Children (AFDC) statute, 42 U.S.C. $\$ 602$ (a) (28) (repealed 1996), and current Medicaid law, 42 U.S.C. $\$ 1396 u-1$ (b) (3) (2000), that prevent states from sanctioning children when their parents violate cash-assistance work requirements, can be seen as either limiting the suffering even of those families that face hardship due to their own fault-answering the second question-or as rejecting vicarious liability of children for their parents' misdeeds-answering the third. The creation and expansion of food assistance, housing subsidy, and public health insurance programs reflect unwillingness to accept hunger, homelessness, and sickness as consequences for the misfortune of poverty (as well as, of course, the embrace of the belief that "[p]overty and immorality are not synonymous," Edwards v. California, 314 U.S. 160, 177 (1941)).

10. We ban extortion, prohibit members of the general public from killing criminals except in limited circumstances, increasingly reject a rule barring tort recoveries by victims who were contributorily negligent, and allow debtors a fresh start through bankruptcy hecause we believe that even problems people brought on themselves should have finite consequences, a merciful response to the second question. We establish standards for occupational safety and health, prohibit usury, and bar some kinds of discrimination in employment and public accommodations because our response to the third question is changing: We no longer regard assent to an oppressive contract or membership in a particular racial group as signifying moral responsibility or bad character. And most of our criminal and tort law is a catalogue of the misfortunes we believe people should not suffer through no fault of their own, an attempt to answer the first question more protectively.

11. For example, environmental law can largely be defined in terms of the constraints imposed upon all economic actors in a particular area, the additional constraints or penalties imposed upon those failing to meet environmental standards, and the content of those standards. Occupational safety and health law, and much of consumer protection law, follows a similar pattern. 
impose a more moderate set of penalties. ${ }^{12}$ Conversely, if the consequences of an adverse moral determination are particularly severe, the criteria for those judgments and the care with which they are applied are likely to come under particularly sharp scrutiny.

The relative importance of these three questions varies over time and across the many areas of social policy. Contemporary liberals, particularly those with a redistributive bent, have grown increasingly accustomed to thinking of social progress in terms of more generous answers to the question of what society will do to prevent innocent suffering. The New Deal was premised on the notion that the innocent elderly, persons with disabilities, widows, and orphans should be ensured some basic protection. ${ }^{13}$ As a society becomes more affluent, it can afford to redistribute more resources to blameless persons facing hardship. This is, however, but one definition of reform, and arguably not the most historically important.

On other occasions, changing answers to each of the other two questions have proven pivotal to social progress. Some of the most rousing advances for civilization have come from redefining bad character, in particular by rejecting status-based moral criteria. ${ }^{14}$ Similarly, social cohesion can be improved by ameliorating the consequences for individuals suffering moral condemnation under whatever standard is currently in place. ${ }^{15}$ To the same effect, we rightfully celebrate those who show clemency to wrongdoers in the cause of enhancing social cohesion. ${ }^{16}$

12. Thus, for example, factors indicating compulsion falling short of full legal justification can mitigate murder down to manslaughter, with a dramatic reduction in penalties.

13. Katz, supra note 9 , at 244 .

14. Most obviously, the recognition that bad character cannot be inherited undermined much of the rationale for serfdom. Rejecting race as a proxy for inferior character isolated apologists for slavery and Jim Crow. The abandonment of property qualifications for voting enriched democracy and marked an important milestone in an as yet incomplete movement away from regarding economic poverty as a mark of moral poverty. See Edwards, 314 U.S. at 177 ("[W]e do not think that it will now be seriously contended that because a person is without employment and without funds he constitutes a 'moral pestilence'."). Freedom for individuals and rich benefits for society at large have resulted when national origin, divergent religious beliefs, gender, sexual preference, and other personal characteristics have been cast aside as bases for inferring an individual's worthiness. See, e.g., Lawrence v. Texas, 123 S. Ct. 2472, 2484 (2003) (prohibiting criminalization of homosexuality); Robinson v. California, 370 U.S. 660, 666-67 (1962) (declaring that one's status, as opposed to one's acts, cannot be criminalized).

15. Long before serfs were freed, enlightened rulers sought to improve their conditions. Long before immigrants received more general civil rights, reformers established settlement houses to relieve suffering in immigrant neighborhoods. The Eighth Amendment's ban on cruel and unusual punishment applies even to those convicted of indisputably heinous acts. Today, abolitionists argue that the death penalty corrupts society, blurring messages about the wrongness of violence.

16. President Abraham Lincoln, Second Inaugural Address (Apr. 10, 1865) (transcript available at http://www.ourdocuments.gov/doc.php?doc+38\&page=transcript) (on file with the Columbia Law Review) (promising "malice toward none" after suppressing 


\section{B. The Limitations on Moral Arguments in Policy Debates}

Although their reach has extended to all three of the basic questions discussed above, the new moralizers have focused first and foremost on the third: reframing the definition of moral fault. In this venture, they follow a long line of thinkers and polemicists. Demands that society recognize morally culpable persons in its midst have great emotional power. They can impel action and upset an established order. Their efficacy in shaping public policy, however, is not unlimited. This subpart identifies four significant factors that have blunted appeals for harsher, more aggressive legal rules weighing individuals' personal moral culpability. Part I.B. 1 notes that expanding moral judgments' scope can cause strife and dissention, undermining social cohesion and incumbent political leaders. Part I.B.2 describes how idealistic overreaching can lead to a cynical reaction that denies the efficacy of moral approaches to public policy. Part I.B.3 observes that elites can manipulate ebbs and flows in the role of moral judgments to help throw off unwanted components of the law. Finally, Part I.B.4 considers the cost and inefficiency of incorporating individualized moral judgments into the law.

1. Preferences for Stability. - Moral arguments are great favorites of reformers and revolutionaries. People can tolerate the tension and uncertainty that moral arguments yield, however, for only so long. Ultimately, a proposed moral principle either is accepted, incorporated into standard practice, and taken for granted, or is rejected as too disruptive or too impractical. Rather than having to sort out what, or who, is moral in each dispute, we develop rules of thumb to make those decisions for us. Similarly, those on the losing side of a moral debate are likely to change their ways, to adapt, or to seek new ways of framing a question so they are no longer cast as malefactors.

Periods when genuinely active moral debate is underway tend to be relatively brief. This is in part because these debates tend to be wrenching and destabilizing. The debates that accompanied many transitions between universal and fault-based rules often juxtaposed emotional appeals to respond to perceived moral crises with more pragmatic arguments purporting to offer efficiency and rigor. ${ }^{17}$ Rigorous analysis of social institutions and problems bestows a different kind of prestige from claims of moral virtue. That prestige is naturally sought by all competitors for power. Those out of power, however, may resort to rigor more safely since they need not fear being held accountable for the institutions' inevitable failure to behave in practice as perfectly as they were conceived. The supposedly scientific socialism of the early Marxists was

the southern rebellion); Wolfgang Amadeus Mozart, La Clemenza di Tito (1791) (portraying Roman emperor's pardon of conspirators in failed plot to kill him).

17. The relationship between emotional and moral arguments, of course, is a complex and contentious one, and it lies well beyond the scope of this Essay. For a discussion of this issue, see, for example, Martha C. Nussbaum, Upheavals of Thought: The Intelligence of Emotions (2001). 
quickly cast aside for a far more passive, domesticated, regimented form of social analysis in countries where avowedly Marxist governments came to power. The ideals of the free market similarly warped into hollow slogans with the rise of rapacious monopolies in the latter part of the nineteenth century.

In addition, rearranging the law's responses to these basic moral questions requires knowledge and understanding of those being judged that is not readily available to most policymakers, reporters, or voters. Whether out of fear or prejudice, middle-class people tend to separate themselves from marginal members of society and hence are likely to be unfamiliar with the pressures and dilemmas that drive some of the behavior that offends middle-class sensibilities. To the same effect, elites have the resources to conceal enough of their activities from public scrutiny to undermine the middle class's capacity to judge them intelligently.

2. Reactions to Overreaching. - Moral arguments may not only fail but may even backfire. Many changes in society's answers to one of the three moral questions result from overreaching efforts to achieve change in the opposite direction. Advocates of greater protection against innocent misfortune appeal to aspirations or guilt. When their proposals fail to achieve the promised results, their beneficiaries violate social norms, or people simply tire of feeling guilty, the resulting disillusionment may give rise to demands for tougher tests of moral virtue. Similarly, advocates of more compassion for the morally culpable sometimes claim they can "improve" those regarded as social deviants. These efforts typically founder due to deficiencies in the basic design of their plans or because the resources available fall short of what is necessary to achieve the moral reform sought. This failure can lead toward either a more punitive version of morality-retribution against those now judged incapable of being reformed ${ }^{18}$-or a self-interested pragmatism that reduces

18. The collapse of the institutionalization movement of early nineteenth-century America illustrates this process. Initially, reformers argued that therapeutic institutions could restore members of important marginal groups-most obviously, the mentally ill, the destitute, criminals, and troubled youth-to productive places in society. Their institutions, however, lacked the capacity to respond to the number of people in these groups, particularly as industrialization, urbanization, and immigration exacerbated social problems. As these institutions faltered, the ideal of rehabilitation collapsed too. Society shifted its goal to custodial incapacitation for those deemed most threatening to society: the mentally ill and, particularly, criminals. Even where retribution did not seem warranted (e.g., with wayward youth and the destitute), the reformative goal collapsed. Instead, society settled for less ambitious interventions-apprenticeships, induction into the merchant marine, and tiny "outdoor relief" payments-which removed the most visible signs of the problems and allowed society to distance itself from them. See generally David J. Rothman, The Discovery of the Asylum 237-64 (1971) (describing abandonment of reformatory institutions as remedies to a range of social ills in the middle of the nineteenth century).

Would-be reformers often overreach when they seek to take responsibility for the outcomes of their policies. House Speaker Newt Gingrich discovered this in the aftermath of the 1994 election. The Contract with America platform on which Gingrich had led 
the law's reliance on distinctions between innocent and blameworthy persons. ${ }^{19}$

\section{Shifting Priorities of Elites. - Powerful groups sometimes benefit} from a legal regime that relies more heavily on determinations of moral worthiness; at other times, they prefer a more efficient system that makes fewer attempts at weighing culpability. As a result, periods of heightened prominence of that moral question can begin and end with changes in the needs of political and economic elites. At the dawn of the Industrial Revolution, the rigidity of common law writs posed a major obstacle to the new entrepreneurs. The intensity of activity that industrialization brought necessarily caused injuries to others. If each new activity had to pay damages to any established one that it might be displacing, no matter how unproductive the latter might be, industrialization could have been stopped dead in its tracks. For example, the Industrial Revolution would have been impossible without railroads, but the railroads of the day were constantly running into people and livestock, setting fields and cities ablaze, and mangling the bodies of their operators. Accordingly, judges moralized the problem: An honest industrialist who had not been negligent should not be held liable in damages like a common ruffian. ${ }^{20}$ In

Republicans to retake the House had proposed to give states money to place in orphanages the children of families whose benefits were terminated under the Republicans' welfare proposals. After the election, Gingrich undertook a spirited defense of the benefits of orphanages. See, e.g., William M. Welch \& Leslie Phillips, Orphanage Idea Brings an Outcry: A Heated Debate over GOP Idea, USA Today, Dec. 6, 1994, at 4A. As a political firestorm erupted, his colleagues convinced him that offering these children no palliative at all was better than becoming associated with one as harsh as an orphanage (and, by proposing it, implicitly acknowledging that the welfare legislation would cause severe hardship). R. Kent Weaver, Ending Welfare as We Know lt 274-76 (2000).

19. Campaigns for harsher treatment of the morally culpable can overreach and collapse as well. An outlaw in early English law was a "friendless man," not only could others abuse him with impunity, they were under a legal duty to do so should the opportunity arise. 1 Frederick Pollock \& Frederic William Maitland, The History of English Law 476-78 (1968); see also 2 id. at 449 (explaining how it was "the right and duty of every man to pursue [an outlaw], to ravage his land, to burn his house"). Presumably because it proved so effective at winning the attention of defendants, the common law's functionaries came to apply it more and more frequently. See J.H. Baker, An Introduction to English Legal History 53 (1979) (explaining how defendants were considered in default for not appearing before the court); 1 Pollock \& Maitland, supra, at 476-77 (noting the rapid spread of the process of outlawry in the fourteenth century). Far from being reserved for the most morally repugnant offenders, it became a fairly standard means of handling failures to appear in court-including defaults by those who had had no notice of the action against them. 2 id. at 580-82. Judgments of outlawry came to outnumber death sentences ten times over. Id. at 557. The common law courts eventually found themselves spending a good deal of time adjudicating requests to lift or void judgments of outlawry. Id. at 581-82. These case-by-case adjudications of whether the defaulters deserved such a dreadful sanction were obviously inefficient and wasteful. Not surprisingly, they gave way to a more routinized process that did not involve the moral invective and ill-targeted overkill of outlawry.

20. See Morton J. Horwitz, The Transformation of American Law, 1780-1860, at 85-101 (1977) (describing the rise of the negligence concept); Morton J. Horwitz, The 
effect, they allowed industrialists embodying the ascendant values of free enterprise to redistribute value from the victims of their mishaps to themselves.

Once industrialization had taken hold, however, the urgency of seeing these issues in moral terms subsided. A range of doctrines of strict liability reasserted themselves, some in legislation and others in case law. ${ }^{21}$ These fault-free liability rules protected wealth that the industrialists had been able to amass under fault-dependent liability rules against other actors engaging in similarly destructive conduct. To the extent that negligence remained a basis for liability, the growth of insurance, and the resulting settlement of disputes by negotiation rather than litigation, obviated the need for judgments of individuals' moral fault in most cases.

4. The Cost and Inefficiency of Individualized Determinations of Fault. Historically, assessments of individuals' supposed virtue have been based all too often on the easy-to-administer but profoundly odious grounds of bigotry: Race, national origin, gender, sexual orientation, and class have provided the criteria for distributing either beneficial or harsh treatment. As these relatively inexpensive bases of making purportedly moral judgments are cast aside, adjudicating individuals' worthiness requires costlier factual inquiries. Although it would be difficult to find a more errorprone method of adjudicating moral fault than bigotry, its perpetrators presumably ignore or accept that risk. The risk of error in fact-based moral assessments, on the other hand, is difficult for even those making the assessments to ignore. Adjudicating someone's actions is expensive and unreliable; adjudicating someone's state of mind is even more so. ${ }^{22}$ Furthermore, frustrations with the unreliability and cost of efforts to base moral judgments on an individual's state of mind can trigger a strong backlash that seeks to find ways of constructing social policy that do not depend on determining individual worthiness at all. ${ }^{23}$ Where this effort succeeds, social policy depends only on our answer to the question of what assistance we should provide to the blameless.

Transformation of American Law, 1870-1960, at 113-16 (1992) [hereinafter Horwitz, Transformation, 1870-1960] (describing debates in the latter half of the nineteenth century about the extent to which private law should punish moral culpability); see also Lawrence M. Friedman, A History of American Law 409-11, 416-17 (1973) (describing tort law's insistence on finding moral fault before imposing liability in the 1ndustrial Revolution); James Willard Hurst, Law and the Conditions of Freedom in the NineteenthCentury United States 19 (1956) (explaining nineteenth-century law as opposed to finding liability for damages absent wrong-doing).

21. See Horwitz, Transformation 1870-1960, supra note 20, at 126-27 (explaining the dissatisfaction of some in the judiciary with the state of strict liability in tort law); see also Friedman, supra note 20, at 426-27 (noting that even liberal judges scorned strict liability rules).

22. Cf. Deborah L. Rhode, Moral Character as a Professional Credential, 94 Yale L.J. 491 passim (1985) (describing the difficulties of inferring character from particular actions with sufficient reliability to justify professional licensure decisions).

23. See supra Part I.B.2. 
It is easy to paint this reduction in the role of judgments of individuals' moral character as the work of liberals who remain suspicious of many of the criteria still being relied upon to make those judgments. This, however, is only part of the story. The values employed in moral judgments are subject to criticism, but the very notion of making those judgments is at least as controversial. ${ }^{24}$ Relatively little attention today is paid to the portion of Justice Harlan's dissent in Lochner $v$. New York that criticizes the moral criteria the Court relied upon to reject maximum hour limitations on bakers. ${ }^{25}$ This portion of his dissent can be seen as representing the progressive critique of laissez faire economics as a basic moral value. Instead, the enduring focus remains on Justice Holmes's dissent, condemning the Court for presuming to make moral judgments at all. ${ }^{26}$ Similarly, First Amendment jurisprudence has increasingly rejected the state's authority to make any value judgments about the content of the speech it is regulating. ${ }^{27}$ In addition, many argue that we long have applied the sanctions of the criminal law to problems it cannot ethically address. ${ }^{28}$

More generally, as the nation grew and the economy became more complex and required more and more routine transactions, the costs of complex adjudications relating to those transactions became increasing impediments to business. Even if only a small and declining fraction of transactions required adjudication, the rapidly increasing number of transactions made that a serious cost. This rise in cost was particularly true where the determination required the kind of subjective appraisal of an actor's state of mind necessary to determine her or his moral culpability. ${ }^{29}$ Thus, it became more efficient to adjudicate compliance with a

24. The concept of avoiding individualized assessments of moral culpability need not imply that the resulting decisions lack moral content. A considerable leap of faith is required to suppose that truly value-neutral grounds for decisionmaking can be developed in important areas of public policy. See, e.g., Herbert Wechsler, Toward Neutral Principles of Constitutional Law, 73 Harv. L. Rev. 1, 1 (1959) (arguing for deciding cases on the basis of "reasoning and analysis which transcend the immediate results"). At most, perhaps, individual policy decisions may have moral content that does not presuppose a broad ideological doctrine. See Rawls, supra note 6, at 175-76.

25. 198 U.S. 45, 70-72 (1905) (Harlan, J., dissenting).

26. Id. at 74-76 (Holmes, J., dissenting).

27. E.g., Republican Party of Minn. v. White, 536 U.S. 765, 788 (2002) (striking down restrictions on content of judicial candidates' campaigning); Simon \& Schuster, Inc. v. Members of the N.Y. State Crime Victims Bd., 502 U.S. 105, 123 (1991) (invalidating statute requiring surrender of proceeds from books describing the authors' crimes); Boos v. Barry, 485 U.S. 312, 334 (1988) (striking down restrictions on displays critical of foreign governments).

28. See, e.g., 1 Joel Feinberg, The Moral Limits of the Criminal Law (1984) (asserting that only actual harms and serious offenses to others merit criminal sanctions).

29. The resulting rules of decision are not "neutral" in the unrealistically optimistic sense of not favoring any particular set of actors or implicitly reflecting any particular normative preference. 1nstead, they merely are designed to avoid or reduce empirical debates about the intent of the actors whose rights are being determined. See Gerald Dworkin, Non-Neutral Principles, in Reading Rawls 124, 135-40 (Norman Daniels ed., 
clear formal requirement than to sort out whether an individual knew something or even whether she or he should have known it. ${ }^{30}$

\section{The Inadequacy of Technical Responses to Moral Arguments}

Although social science can and should inform decisions on each of these three issues, they are, first and foremost, moral questions. They may be answered differently for different populations, but at the heart of any social policy or system of policies are expressed or implied answers to these three questions. These questions-and various actors' efforts to focus or obscure the debate on any of them-long have permeated struggles over social policy in the United States.

Because disputes involving the third question-the moral bases on which culpability may be assessed-demand the most time and attention from judges and lawyers, that question tends to receive the most attention in legal literature. It may be answered in several possible ways. One objective approach is to assign moral consequences to an individual's status. Throughout history, the family, clan, tribe, nationality, or race into which an individual was born often has served as the basis for determining that individual's moral standing. Gender, age, religion, sexual preference, parents' marriage, and other conditions have provided those of dominant status with a simple, convenient way of passing judgment on others. Another objective approach is to base judgments on an individual's actions. Someone who goes into a crowded public place and opens fire at strangers is judged to be morally blameworthy. This method of assessing fault may require determination of the individual's actions in some cases, but once determined, an objective rule can specify the moral consequences of those actions. Finally, moral fault can be assessed subjectively based on an individual's presumed state of mind. Objective factors-the

1989) (stating that because principles such as truth, morality, and justice "cannot command general agreement ... [they] must be replaced by principles whose application to particular cases commands widespread agreement").

30. Thus, it is easier to determine if a creditor filed a security interest than to examine other parties' states of awareness. Similarly, liability when fraudulent commercial paper is transacted depends on a party's position in the chain of handling of the document, whether or not he or she had any plausible opportunity to prevent the fraud. Violating certain regulatory standards results in strict tort liability, without regard to the moral culpability implicit in negligence. Costly and error-prone automobile negligence trials largely have been replaced with no-fault insurance. Bitter and often dishonest divorce proceedings have been replaced with "no-fault" procedures in many states. The Statute of Frauds denies enforcement to certain important contracts-those that convey land, that will bind the parties for more than a year, or that involve substantial sums of moneyunless made in writing to reduce the risk of perjury about the terms of oral contracts. Persons losing credit and debit cards generally have few defenses to liability up to a specified threshold, no matter how blameless their conduct, and then have fairly sweeping immunity above that level, even if they have been quite negligent. When a term of a contract for the sale of goods is missing, the courts are instructed to insert an objectively reasonable one-which may be determined through a largely impersonal analysis of the market-rather than seeking one that best reflects what the parties intended. 
individual's words and actions-are likely to play a crucial part in that evaluation, but if the verdict requires weighing factors such as intent, justification, negligence, etc., the faultfinding will be fundamentally subjective.

Concerns about the reliability and cost of assessing individuals' moral blameworthiness contributed to a trend throughout much of the twentieth century away from basing legal rights on assessments of individuals' moral virtue. This has led both liberals and conservatives to focus their policy arguments primarily on technical issues. When everyone agrees on the goals to be pursued, discussion naturally moves to how best to realize those goals. Although liberals are accustomed to condemning conservatives for their unsentimental adherence to free-market economics, ${ }^{31}$ liberals, too, often treat important issues of public policy as technical ones rather than moral ones. ${ }^{32}$ Liberals blundered away their credibility on welfare issues in the 1980s and 1990s by treating the issue of work as a technical one rather than as the moral imperative that much of the public saw it as.

Liberals have gravitated toward technical debates for other reasons as well. The liberal coalition may fracture, or place itself far to the left of where swing voters are willing to go, when it seeks to address the question of what society should do for innocent victims of misfortune. ${ }^{33}$ The perfect thus becomes the lethal enemy of the good, ${ }^{34}$ as it did, for example, in the 1993-1994 healthcare reform debate. When debates concern the technical details of existing programs rather than broad principles of social responsibility, more politically savvy liberals often can circumvent

31. For example, Judge Posner was widely condemned for suggesting that free market economics could supply an appropriate set of normative goals for social policy. Compare Posner, Problematics, supra note 2, at 1693-99 (arguing for a separation of law and morality), with, e.g., Ronald Dworkin, Darwin's New Bulldog, 111 Harv. L. Rev. 1718, 1735-37 (1998) (arguing Judge Posner's analysis of efficiency is futile without moral principles to define worthy ends).

32. See, e.g., Anthony T. Kronman, The Lost Lawyer 50-52 (1993) [hereinafter Kronman, Lost Lawyer] (describing the rise and fall of public esteem for the legal profession during the late twentieth century); Donald A. Schön, The Reflective Practitioner 3-9 (1983) (describing the rise and fall of public confidence in the professions generally during this period); see also Steven Brint, ln an Age of Experts: The Changing Role of Professionals in Politics and Public Life 13-19, 129-49 (1994) (discussing the subordination of the traditional liberal agenda to the sensibilities of technical experts).

33. See Charles Noble, Welfare as We Knew It: A Political History of the American Welfare State 112-15 (1997) (describing the alienation of liberals from the American electorate in the late 1960s and 1970s); Trattner, supra note 9 , at 342,358 (describing splits in the liberal community over the adequacy of the improvernents of benefits in the Nixon and Carter welfare reform plans, both of which failed).

34. If every major progressive proposal is tested against what it might have provided, rather than against the status quo, none will be enacted. 
their more radical colleagues. ${ }^{35}$ Liberals, many of whom are social scientists or lawyers, also may feel they have a comparative advantage over conservatives in their ability to debate the technical sides of some issues. ${ }^{36}$ Finally, the decades-long abortion debate, in which antiabortion groups have aggressively insisted that they were seeking to restore morality to public law, likely has soured many liberals on moral policy arguments. ${ }^{37}$

This habit of making technical arguments has left liberals-as well as traditional conservatives-ill equipped to respond to challenges to their underlying assumptions about the basic goals of law and public policy. Nowhere has this been more apparent than in public benefits law. Liberals have become accustomed to framing discussions of welfare policy in terms of "what works." 38 This presupposes that we all agree on what we want to accomplish. Given how incendiary, and often racially tinged, welfare debates have been, liberals and moderate conservatives have sought to paper over those differences and convert welfare policymaking into a largely technical exercise. For a couple of decades, these groups engaged in a highly technical debate about how best to enhance the employment of welfare recipients, whether motivated by incentives or penalties, and whether through skills training, immediate job search, or unpaid work experience. The goal of improving recipients' incomes, however, was widely shared.

The antiwelfare campaign of the early 1990s caught both liberals and traditional conservatives unaware precisely because it rejected that goal, at least for a substantial group of claimants. That technical issues must ultimately be subordinate to moral ones can be seen by examining the frequently asked technocratic question: What is the most effective way to get low-income people off of welfare? The incontrovertible answer is to stop writing checks. Ending welfare, "as we know it" or otherwise, has

35. Someone who sees an issue as a "matter of principle" may feel less of a need to master its technical details than someone who is seeking to craft a proposal that can win political approval.

36. See, e.g., Kronman, Lost Lawyer, supra note 32, at 195-209 (describing the tendency of lawyers and legal academe to pursue comfortable technical arguments over unsettling normative ones). More generally, people who choose to devote their careers to developing expertise in human services issues tend to be liberals. Often enough, bright conservatives want to make money while many bright liberals want to make policy. A conservative who values private enterprise highly may develop business skills that give her or him the capacity to earn far more than she or he would in government, policy research, or academe; less business-oriented liberals may not develop those skills and hence may suffer less of a financial loss going into public service.

37. See, e.g., Laurence H. Tribe, Abortion: The Clash of Absolutes 239 (1990) (describing abortion opponents' denunciation of "those who favor choice as morally blind").

38. See, e.g., Fighting Poverty: What Works and What Doesn't 15-17 (Sheldon H. Danziger \& David H. Weinberg eds., 1986); see also, e.g., Mary Jo Bane \& David T. Ellwood, Welfare Realities: From Rhetoric to Reform 124-33 (1994) (expressing views of two Clinton Administration subcabinet members and basing welfare reform proposals in practical rather than moral terms). 
never been any more technically complicated than turning off a spigot. The reason we do not take this simple but effective approach to removing people from the reviled welfare program is that doing so would cause hardship for the families involved, and that would violate our moral principles: It would inflict more harm on innocent victims of misfortune than we are willing to allow. The extent and limits of those principles, therefore, become the fundamental question from which all others must flow.

Little is new about liberal reformers' habit of immersing themselves in technical squabbles while the moral consensus on which goals should be pursued crumbles away. Early nineteenth-century prison reformers became so consumed in essentially technical debates between their competing models of corrections that they failed to appreciate until it was much too late that most of society had shunted aside their rehabilitative goals in favor of custodial models of incapacitation and retribution. ${ }^{39} \mathrm{~A}$ shift in society's response to the second basic moral question-what hardships should befall the blameworthy-effectively mooted the reformers' intramural technical debate.

In the same way, technical debates over how to analyze the environmental impact of certain kinds of risky behavior can resolve policy disputes only if a consensus exists that inflicting the type of environmental damage at issue is morally blameworthy and hence an appropriate concern for public policy. Technical issues can similarly be brushed aside by more fundamental moral disputes in a host of other public policy areas, from Social Security to civil rights to antitrust. In the end, although administrative issues play a crucial role in determining how social programs will affect their intended beneficiaries and be perceived by the public, they cannot even begin to be addressed until it is first determined what goals a program is intended to achieve. And, in many areas of social policy, at least in the first instance, that is a fundamentally moral question.

\section{I1. The New Moralizers' Manipulation of Moral Tests in Public Policy}

Although advocates of a particular test of moral fault like to suggest that it has the virtue of simplicity-describing it with terms such as "common sense"- the reality tends to be quite different. Even where a general consensus exists about the evil to be fought or the good to be championed, a host of complex questions remain about defining the moral test and enforcing it. Appreciating the consequences of the various alternatives requires a sophisticated understanding both of the circumstances of those being regulated and of the capabilities of those charged with enforcing the regulations. To judge a company morally blameworthy based on the amount of pollutant its factory emits, one must not only understand the harm the pollutant may do but also the alternatives to emission. To judge a welfare recipient morally blameworthy for not getting a job,

39. See Rothman, supra note 18 , at $79-88,237-57$. 
one must understand his or her skills, the local job market, and the availability of child care and transportation, among other things. ${ }^{40}$ Most policymakers and members of the media-to say nothing of voters-are ill equipped to make those judgments. Therefore, whoever crafts these tests has enormous opportunities to insert covert preferences into the law, making it much easier or harder for members of a particular group to be found morally blameworthy than is widely understood. ${ }^{41}$ Similarly, the impact or severity of many kinds of hardships, whether imposed on the innocent or the culpable, may be difficult for people in different circumstances to appreciate. ${ }^{42}$ These largely unseen and unappreciated effects are much of what makes the new moralizers' agenda so important.

More broadly, the new moralizers seek to shift the nature of this country's responses to the three basic moral questions as it formulates public policy. An optimistic, forward-looking society debates the first of the questions: what reforms it ought to implement to help its less fortunate members. A pessimistic, fearful, even bitter society focuses instead on the second and third, asking what it must do to impose moral standards on those it sees as afflicting it. Disillusionment with failed altruistic reforms certainly can help transform the emphasis from the moral duties of society to those of individuals. ${ }^{43}$ It is nonetheless remarkable how effectively the new moralizers persuaded Americans to adopt the harsh moral tone of an embittered society in the 1990s despite a booming economy, declining crime rates, and the collapse of the only foreign enemy that could pose a mortal threat to this country.

The contemporary new moralizers' agenda seeks to reinvigorate both the issue of which individuals should be considered worthy of government favor and that of how unworthy individuals should be treated. If enough people can be deemed unworthy and dealt with severely, the scope of protections to be afforded to the morally virtuous becomes comparatively less important. ${ }^{44}$ In addition, the new moralizers have sought

40. Even if a policymaker believes it possible to evaluate a particular polluter's alternatives or a particular welfare recipient's opportunities given sufficient resources, she or he also must determine whether those charged with implementing the regulatory system can make those judgments accurately given the resources available to them.

41. Thus, for example, a rule requiring a prospective immigrant to demonstrate a likelihood of persecution to avoid deportation may sound reasonable to people who are iguorant of human rights problems. Those implementing the rule, however, may be able to skew adjudications against people escaping from a certain country by demanding documentation of a kind rarely, if ever, available under that country's system.

42. Someone who has never been in prison is unlikely to appreciate the effects of solitary confinement. Someone with fully stocked cupboards and friends financially able to help will have difficulty comprehending the impact of a loss of income to an already impoverished family.

43. See supra part 1.B.2.

44. Put simply, a policy that affects an entire population because it depends on no determinations of worthiness is more important than one that only applies to the half of that population that is determined morally blameless. 
to develop morally compelling arguments for rolling back policies protecting the faultless.

Part 1I.A discusses the core of the new moralizers' agenda: imposing and manipulating rules to change the way in which the law assesses an individual's moral culpability. The severity of these moral tests varies strikingly depending on whether they are applied to elites or politically marginal groups; indeed, the new moralizers' rules sometimes presume fault in the latter groups with little basis. Part II.B shows how the new moralizers have escalated the penalties visited on many of those failing one of these morality tests. Finally, Part II.C describes the new moralizers' audacious incursion into the traditional liberal realm of advocating policies for the concededly blameless. As will be seen, the new moralizers' impact varies considerably across public policy areas. The terms of debate in environmental law, for example, have changed far less than those concerning public benefits or child protection. Nonetheless, the new moralizers' impact has been strikingly pervasive.

\section{A. Transforming the Tests of Moral Blameworthiness}

Throughout history, people feeling vulnerable to economic dislocations have sought to place the blame for their worries on supposedly immoral individuals. These concerns launch movements that claim to be inserting a stronger moral tone into law. Today, the largely invisible forces of globalization have led to rapid social and economic dislocations that leave many people feeling insecure. It thus should not be surprising that both left and right have sought to channel the public's angst to serve their agendas. The right has been vastly more successful in this effort, offering a far more coherent and marketable program. The villains against whom they have rallied the public are familiar ones who many people are predisposed to distrust, such as prisoners, undocumented immigrants, and welfare recipients. Just as important, the new moralizers have cleverly avoided directly confronting suspicions that some corporate executives and other elites have acted venally. Instead, the new moralizers acknowledge that some in the corporate sector are indeed bad apples but have set the rules for seeking out those malefactors to ensure that only a few are found.

Thus, much of the new moralizers' appeal is their promise to give focus to the public's anxieties by identifying and punishing actual individual malefactors. The result is a government that seeks actively to promote the survival and success of virtuous individuals, in some ways resembling a kind of state-managed social Darwinism. The moral tests the government relies upon, however, are corrupted by virtue of being designed to reflect the contestable assumptions of the new moralizers. If we impose tough tests on those we expect to be immoral and forgiving tests on those we expect to be virtuous, we are likely to find our prejudices vindicated.

In seeking to increase public policy's reliance on tests of character, the new moralizers have three fundamental themes. Part 1I.A.1 addresses 
the first and most conventional: imposing harsh rules that treat ambiguous activities already taking place in society as per se immoral. Part 1I.A.2 considers a more novel strategy: confronting members of marginal groups with artificial tests in which they must prove their worthiness. Finally, Part II.A.3 examines the new moralizers' treatment of favored elites, which is in many ways the reverse of their other strategies. Here, they seek to replace broad prophylactic rules affecting all members of a class with narrow rules that constrain only those determined blameworthy under very forgiving standards.

1. Scrutinizing Existing Behavior. - By far the most traditional application of morality in law is to pass judgment on behavior that already exists in society. As noted, however, the civil rights advocates' aversion to status-based determinations of morality and business interests' antipathy for costly adjudications have advanced a pragmatic system of objective rules that seek to minimize the need for individualized moral judgments. This confronted the new moralizers with two challenges in returning individualized moral judgments to the fore in U.S. public policy. First, they needed to persuade the public that immorality was such an important source of social problems that tests of moral character were necessarythat it was important to judge people rather than just attach consequences to conduct. Second, they had to devise moral tests that would not be overly burdensome to administer but that would avoid the overt injustices of status-based tests such as race and gender. It is particularly their success in the latter enterprise that distinguishes the new moralizers' work from past denunciations of the "unworthy poor," criminals, and immigrants, among others.

The first task was accomplished largely by reviving old morality critiques. ${ }^{45}$ Welfare recipients were criticized for supposed laziness and promiscuity as had been common up through the 1960s (and periodically since) ${ }^{46}$ Debtors again were branded as irresponsible spendthrifts; their supposed moral faults justified restricting access to a fresh start through bankruptcy. ${ }^{47}$

45. Linguist George Lakoff describes this process as persuading the public that society needs a stern parent more than it needs a nurturing one. George Lakoff, Don't Think of an Elephant! Know Your Values and Frame the Debate 5-9 (2004).

46. See, e.g., Press Release, Heritage Found., How "Poor" Are America's Poor: U.S. Census Bureau "Poverty" Report Gives Distorted Picture, Says Heritage Study (Sept. 24, 1990) (on file with the Columbia Law Review) [hereinafter Heritage Found., America's Poor] (quoting Heritage Foundation analysts' assertions that welfare spending "destroys ... work ethic [and] family structure").

47. See, e.g., 147 Cong. Rec. H524 (daily ed. Mar. 1, 2001) (remarks of Rep. Chabot) (criticizing "irresponsible debtors"); id. at H595 (remarks of Rep. Goodlatte) (alleging that "some irresponsible people filing for bankruptcy run up their credit card debt immediately prior to filing, knowing that their debts will soon be wiped away"); Dick Armey \& Randy Tate, Heritage Found., Freedom and Responsibility: The Role Values Play in Shaping Public Policy 4 (Apr. 20, 1998), available at http://www.heritage.org/Research/Political Philosophy/loader.cfm?url/commonspot/security/getfile.cfm\&:PageID=19589 (on file 
At their most insidious, judgments based on these kinds of per se rules may have the effect of offering a patina of legitimacy for old-fashioned bigotry. If one starts from the premises that it is immoral to take a job based on race that one did not "deserve" and that affirmative action programs are pervasive, it is a small step to the conclusion that successful African Americans and Latinos may be stigmatized precisely because of their success. ${ }^{48}$ Less successful minority individuals, of course, can be stigmatized on the basis of their actual shortcomings, creating an inescapable bind. To the same end, the "don't ask, don't tell" policy conveys to gays and lesbians that while they may not be punished for the status of their sexual preference, they can be punished for the act of admitting who they are. Just as critics of affirmative action seek to portray women and racial minorities as threatening the jobs and educations of men and whites, so too, antigay themes are justified by conjuring a mythical assault on marriage that calls for a "defense." 49

To similar effect, some new moralizers have called for reviving the epithet of "illegitimacy," stigmatizing children for conduct of their parents that they could not possibly control. ${ }^{50}$ More generally, the new moralizers have been quite willing to inflict harm on children in the course of punishing their parents' "morally objectionable" conduct. New moralizers attacking domestic food assistance programs have made a point of suggesting that beneficiaries are obese, a condition that many people persistently, if inappropriately, associate with moral failure. ${ }^{51}$

The preference for moral arguments that criticize individuals can be seen in the shift in the rhetoric of the antiabortion movement. Attacks on "abortion on demand" suggest that women treat this decision as casu-

with the Columbia Law Review) (reminiscing about a time when "bankruptcy was a matter of embarrassment").

48. See, e.g., Carl Cohen, Heritage Found., Race Preference in College Admissions 4 (Apr. 29, 1998), available at http://www.heritage.org/Research/Education/loader.cfm?url $=/$ commonspot/security/getfile.cfm\&PageID=19657 (on file with the Columbia Law Review) (hypothesizing that "[race] preference . . . creates a link between the minority preferred and inferior performance").

49. See, e.g., The Defense of Marriage Act, Pub. L. No. 104-199, 110 Stat. 2419 (codified at 1 U.S.C. $\$ 7(2000)$ and 28 U.S.C. $\$ 1738 \mathrm{C}(2000)$ ) (defining marriage exclusively as between a man and a woman and stipulating that no state shall be required to recognize same-sex marriages).

50. See, e.g., Joseph J. Piccione \& Robert A. Scholle, Heritage Found., Combatting Illegitimacy and Counseling Teen Abstinence: A Key Component of Welfare Reform 21 (Aug. 31, 1995), available at http://www.heritage.org/Research/Welfare/BG1051.cfm (on file with the Columbia Law Review) (criticizing lack of stigma for out-of-wedlock births); Dennis Prager, Heritage Found., The American Tradition of Personal Responsibility (Sept. 20, 1994), available at http://www.heritage.org/Research/PoliticalPhilosophy/HL515.cfm (on file with the Columbia Law Review) (arguing to revive the stigma of out-of-wedlock births).

51. See, e.g., Douglas J. Besharov, We're Feeding the Poor as If They're Starving, Wash. Post, Dec. 8, 2002, at B1; Robert E. Rector, Today's Special: Another "Hunger Crisis," Nov. 21, 2000, at http://www.heritage.org/Press/Commentary/ed112100c.cfm (on file with the Columbia Law Review). 
ally as ordering a pizza. Similarly, the focus on late-term "partial birth" abortions allows new moralizers not just to criticize a procedure that lends itself well to sensationalization but also to condemn the women that waited long enough for this procedure to become necessary. ${ }^{52}$ Thus, restrictions on this procedure can be portrayed as affecting only careless, blameworthy individuals rather than the rights of women generally. This focus on a particular subset of women having abortions otherwise would seem a distraction from antiabortionists' traditional emphasis on the moral duties they have argued society owes to fetuses.

Part II.A.1.a describes the growth of rules that implicitly presume moral culpability from actions that may have quite innocent explanations. Part II.A.1.b suggests that, by framing these judgments as per se rules, the new moralizers are likely to avoid the judicial scrutiny that would result from attempts to test individuals' actual states of mind. And Part II.A.1.c provides an example of how the new moralizers have extended this approach to private law.

a. Determining Immorality with Arbitrary Per Se Rules. - The traditional Achilles' heel of rules requiring individualized moral judgments has been the administrative cost and burden of the required adjudications. To avoid this problem, the new moralizers have called for objective determinations of morality based on arbitrary per se standards. ${ }^{53}$ These standards typically have little to do with the actual state of mind of the individuals being judged, but the inferences they draw are likely to seem plausible to middle-class policymakers, reporters, and voters that have little contact with the judged individuals. For example, the 1996 welfare law, the Personal Responsibility and Work Opportunity Reconciliation Act (PRWORA), judges families that have received five years of cash assistance-no matter how meager the amount-to have exhausted their moral claim on society. ${ }^{54}$ Obstacles to employment-disability in a parent or a child, domestic violence, a depressed job market, a shortage of reliable child care, etc.- the family faced during that time, or the level of effort expended by the parent in seeking work, is irrelevant to this moral

52. These waits may have been beyond the control of the women if they lacked the funds to pay for abortions since the federal government and most states prohibit spending their Medicaid funds on abortions. See Harris v. McRae, 448 U.S. 297, 309-11 (1980) (holding states free to deny Medicaid coverage for medically necessary abortions).

53. An alternative means of achieving similar ends is to create large incentives, largely invisible to the general public, for coercing individuals to concede their culpability and thus obviate the need for adjudications. For example, grossly underfunding indigent criminal defense so that the accused have little prospect of winning at a trial effectively forces plea bargains. See, e.g., Darryl K. Brown, Rationing Criminal Defense Entitlements: An Argument from Institutional Design, 104 Colum. L. Rev. 801, 805-07 (2004) (discussing states' disinclination to adequately fund indigent criminal defense). Similarly, public welfare systems increasingly depend upon coercing eligible claimants not to apply. David A. Super, Offering an Invisible Hand: The Rise of the Personal Choice Model for Rationing Public Benefits, 113 Yale L.J. 815, 891-93 (2004).

54. 42 U.S.C. $\$ 608(a)(7)(2000)$. 
calculus. ${ }^{55}$ A few months earlier, the Contract With America Advancement Act (CWAAA) directed the Social Security Administration to ignore disabilities resulting from substance abuse when determining eligibility for Social Security Disability Insurance and Supplemental Security 1ncome (SSI) without regard to whether treatment was available or likely to be efficacious. ${ }^{56}$

The Adoption and Safe Families Act of 1997 (ASFA) deems parents' moral fitness to retain tbeir rights as parents suspect if their children have been in foster care for fifteen of the last twenty-two months, regardless of the problems of either parent or child or of the level of services provided to help the family reunify. ${ }^{57}$ ASFA's advocates promote this harsh judgment on distressed parents as a pragmatic effort to bring stability to the children involved through adoption. ${ }^{58}$ Yet the hard fifteen-month dead-

55. To be sure, states' applications of time limits bave varied considerably. About half of the states imposed time limits shorter than sixty months. For example, Tennessee limited spells of assistance to eighteen months, Tenn. Comp. R. \& Regs. 1240-1-51$.01(1)$ (a) (2004), while Connecticut imposed a lifetime limit of twenty-one months. State Policy Documentation Project, State Time Limits on TANF Cash Assistance (2000), available at http://www.spdp.org/tanf/timelimits/tlovervw.pdf (on file with the Columbia Law Review). On the other hand, many states, particularly those that had set time limits shorter than sixty months, allowed some claimants exemptions from or extensions to these time limits. Some of these policies offered little benefit to most claimants, but states' decisions to establish them suggested that preserving at least the appearance of individualized adjudications retains more appeal in some state capitals than it does in Washington.

56. Pub. L. No. 104-121, $\S 105,110$ Stat. 847 (1996) (codified at 42 U.S.C. $\S \S 423(\mathrm{~d})(2)(\mathrm{C}), 1382 \mathrm{c}(\mathrm{a})(3)(J))$. The disqualification of persons disabled by substance abuse, enacted to finance an increase in benefits for working middle-income retirees, replaced bipartisan legislation passed a few years earlier that required substance abusers to receive treatment if available but allowed them to receive disability benefits for two years while they did.

57. Subject to very limited exceptions, AFSA requires a state to petition for termination of parental rights once the fifteen-month mark has been reached. 42 U.S.C. $\$ 675(5)$ (E) (2000). In some cases, the state may avoid the mandate to file such a petition if it admits that it has failed to provide necessary services. Id. $\$ 675(5)$ (E) (iii). The definition of what services are necessary, however, is left to the state; it seems unlikely many states will be prepared to endanger their federal funding by admitting such failures.

58. ASFA's supporters invoked other moral rationales in support of its rigid requirements concerning termination of parental rights: anger at the bureaucrats running child welfare agencies that seemed to be moving too slowly and the compassionate hope that abused and neglected children could find adoptive homes. At its core, however, AFSA applies a per se rule to terminate the most important relationship in parents' and children's lives.

A disproportionate number of the parents losing rights in these proceedings have low incomes. Their poverty often forces them to seek public aid, bringing them in contact with more public agencies' staff who can scrutinize their parenting. A substantial number of findings of neglect results from the lack of basic necessities that are difficult for low-income parents to afford. The steps required to persuade child welfare officials that the parents can provide a suitable home for their children are likely to be costly and hence more difficult for low-income parents to accomplish quickly. And, if the state does seek to terminate parental rights, low-income parents are less likely to be able to afford lawyers and expert witnesses to defend themselves. See Lassiter v. Dep't of Soc. Servs., 452 U.S. 18, 
line applies whether or not the children have any viable prospects of adoption.

Also imposing extremely difficult burdens on families are rules requiring tenants' eviction from subsidized housing if a relative staying in their unit is found to possess illegal drugs, even without the tenants' knowledge. ${ }^{59}$ Tenants who need help with activities of daily living or who value the companionship of family members must weigh those concerns against the possibility that the relative may be concealing a drug problem, even an occasional one. Middle-income homeowners obviously face no comparable sanction for misjudging their relatives.

The Antiterrorism and Effective Death Penalty Act of 1996 (AEDPA) treats the dismissal of a prior habeas corpus petition-even one filed by a legally unsophisticated inmate on his or her own behalf-as an offense sufficient to bar the filing of future petitions except in extraordinary circumstances. ${ }^{60}$ Similarly, the Prison Litigation Reform Act (PLRA) punishes prisoners who have filed three prison condition complaints that were dismissed by denying these prisoners the right to file further complaints without payment of effectively unaffordable filing fees. This bar makes a formal exception when "the prisoner is under imminent danger of serious physical injury"-but by then it may be too late to resort to federal court. ${ }^{61}$ This renders the prisoner a virtual outlaw who can be abused with little fear of recourse to federal court. ${ }^{62}$ The prisoner's state of mind in filing the complaints that were ultimately dismissed is largely irrelevant in imposing this severe sanction. ${ }^{63}$ Thus, while access to the courts is restricted for prisoners deliberately choosing to abuse the legal

32-33 (1981) (finding no right to appointive counsel in proceedings to terminate parental rights despite the proceedings' complexity and the high stakes involved).

59. See generally United States Dep't of Hous. \& Urban Dev. v. Rucker, 535 U.S. 125, 136 (2002) ("Section $1437 \mathrm{~d}(1)(6)$ requires lease terms that give local public housing authorities discretion to terminate the lease of a tenant when a household member or a guest engages in drug-related activity, regardless of whether the tenant knew, or should have known, of drug-related activity.").

60. See 28 U.S.C. $\$ 2244(a)-(b)(2000)$.

61. 1d. $\$ 1915(\mathrm{~g})$. Since these restrictions are tied to the right to file lawsuits without payment of fees, they only limit impecunious prisoners. The wealthy incarcerated mob boss is free to file as many lawsuits as he or she wishes without regard to the fate of his or her earlier filings. This highlights how severely flawed this rule is as a moral test: The minority of prisoners who can afford to pay their own filing fees are far more likely to have access to legal guidance-and thus are far more likely to have known that their earlier petitions were at least pushing the limits of established law. It should be noted that this procedure for automatically denying prisoners the right to file litigation over prison conditions is in addition to the longstanding practice of judges requiring permission for further filings from particular prisoners who have repeatedly abused the process. The PLRA's approach differs in that it effectively exempts prisoners who can afford to pay filing fees and it does not require a finding of culpability.

62. See supra note 19 .

63. These penalties are in addition to those-including loss of "good time" credit toward release from custody-that the PLRA imposes on prisoners who are adjudged to have filed a complaint in subjective bad faith. 28 U.S.C. $\$ 1932$. 
process, it is also denied to victims of innocent misunderstandings of the requirement to exhaust administrative remedies or of the complex and indeterminate state of Eighth Amendment law ${ }^{64}$ and those whose lack of education or emotional instability cause them to file claims that seem incredible to middle-class judges accustomed to reading the pleadings of educated lawyers. ${ }^{65}$

AEDPA similarly prohibits many immigrants from fleeing persecution to the United States. It prohibits the courts from considering pleas for political or religious asylum from those who entered the United States "without inspection"- that is, those who entered the country somewhere other than an official port of entry. ${ }^{66}$ The Illegal Immigration Reform and Immigrant Responsibility Act of 1996 (IIRIRA) took this one step further to make such immigrants ineligible for admission on any basis. ${ }^{67}$ Here again, intent is largely irrelevant: The rule generally applies without regard to why the immigrant entered as she or he did. Someone who has been badly abused by a repressive regime may be focused exclusively on escaping to the United States and may be too traumatized to appreciate the niceties of immigration procedure, yet the prohibition applies nonetheless. AEDPA and IIRIRA also treat numerous relatively petty offenses as involving "moral turpitude" and hence bar many immigrants from seeking legal status. ${ }^{68}$

b. Straddling the Line Between Adjudications of Fault and Legislative Classifications. - Any recourse against these rules is likely to come from the

64. Compare, e.g., Clemmons v. Bohannon, 956 F.2d 1523, 1525 (10th Gir. 1992) (en banc) (affirming grant of summary judgment against prisoner claiming that exposure to second-hand smoke violated Eighth Amendment), with Helling v. McKinney, 509 U.S. 25, 35 (1993) (finding that such exposure could constitute cruel and unusual punishment). Even treatment that would strike many laypeople as cruel and unusual has been insufficient to support an Eighth Amendment claim. See, e.g., Thomas v. Greene, No. 993179, 1999 WL 1253102, at *1 (6th Cir. Dec. 17, 1999) (affirming dismissal of an excessive force suit by prisoner whose clothes were saturated with chemical mace by guards).

65. Prisoners' claims may be dismissed as frivolous even if they could not be dismissed under the standard Rule 12(b)(6) that applies to other litigants, which requires the court to presume the truthfulness of the plaintiff's assertions for purposes of a motion to dismiss.

The Supreme Court explained the difference between a Rule 12(b) (6) dismissal and the pre-PLRA section 1915: Section 1915, unlike Rule 12(b)(6), "accords judges not only the authority to dismiss a claim based on an indisputably meritless legal theory, but also the unusual power to pierce the veil of the complaint's factual allegations and dismiss those claims whose factual contentions are clearly baseless."

Bilal v. Driver, 251 F.3d 1346, 1349 (11th Cir. 2001) (quoting Neitzke v. Williams, 490 U.S. $319,327(1989))$.

66. 8 U.S.C. $\$ 1182(a)(6)$ (A) (i) (2000).

67. Pub. L. No. 104-208, div. C, $\S 301,110$ Stat. 3009-546, 3009-575 to 3009-577 (1996) (codified in scattered sections of 8 U.S.C.).

68. 8 U.S.C. $\$ 1227$ (a) (2) (A) (i) (defining a "crime of moral turpitude" as any offense that could have been punished with at least one year's imprisonment, even if the actual sentencing judge determined that a lesser sentence was appropriate in the immigrant's particular case); see also id. $\$ 1101(\mathrm{a})(43)(\mathrm{J})$ (defining "aggravated felony" similarly based on the possible sentence, not the one a judge found appropriate). 
political process, not the courts. Although the new moralizers advocate these rules in the guise of finding fault, they do not explicitly adjudicate fault. Thus, the Due Process Clause seems unlikely to provide much recourse even though the reliance on per se tests to determine individuals' morality is likely to produce many erroneous results. In most of these areas, legislative classifications are subject only to "minimum rationality" scrutiny. ${ }^{69}$ On some occasions, the Court has treated the state's infliction of moral stigma as having a significance above and beyond the implications of any substantive actions the state took, ${ }^{70}$ but when confronted in Weinberger $v$. Salfi with a per se rule denying widows benefits on the accounts of men they had married relatively recently, the Court chose to ignore the evident stigmatization of these women as opportunists and treated it as a routine legislative classification. ${ }^{71}$ Since the moral opprobrium resulting from many of the new moralizers' rules is similarly tacit, it seems unlikely that the Court would require that those running afoul of these rules have the opportunity to show extenuating circumstances. Although the restrictions on immigrants' and prisoners' access to the courts would seem to impinge more directly upon recognized constitutional rights, to date the courts have upheld these laws. ${ }^{72}$

c. Imposing Per Se Morality Tests in Private Law. - This trend toward objective tests of moral character has reached into private law as well. Perhaps the most striking example is in the law of consumer bankruptcy. The Constitution's only explicit provision for the indigent is the Bankruptcy Clause. ${ }^{73}$ As the federal government's oldest program for low-income people, it long has been described as an opportunity to give a fresh start to someone mired in a morass of debt in terms assuming innocent misfortune. ${ }^{74}$

69. See, e.g., Dandridge v. Williams, 397 U.S. 471, 526-27 (1970) (finding rationality review appropriate for most rules concerning public assistance).

70. See, e.g., Goss v. Lopez, 419 U.S. 565, 574-75 (1975) (finding the injury to the reputation of a suspended student important in determining that the suspension implicated liberty interests); Wisconsin v. Constantineau, 400 U.S. 433, 436 (1971) (finding deprivation of liberty in a system allowing police chief to designate individual a public drunk). But cf. Paul v. Davis, 424 U.S. 693, 711-12 (1976) (finding no liberty interest implicated where moral stigma was not backed by any state-imposed sanctions).

71. 422 U.S. 749, 768-85 (1975).

72. See, e.g., Rivera v. Allin, 144 F.3d 719, 732 (11th Cir. 1998) (upholding PLRA's restriction on suits by prisoners with three prior actions dismissed even when those dismissals occurred prior to PLRA's enactment). On the other hand, the Supreme Court did strike down, albeit on different constitutional grounds, one set of per se rules: term limits that presume members of Congress incapable of continuing to represent their constituents' interests after a certain number of years in office. U.S. Term Limits, Inc. v. Thornton, 514 U.S. 779 (1995); see also Cook v. Gralike, 531 U.S. 510, 524-27 (2001) (striking down on First Amendment grounds Missouri requirement that congressional candidates' failure to pledge support for term limits be noted on ballot).

73. U.S. Const. art. I, $\S 8$, cl. 4 .

74. "It is the purpose of the Bankrupt Act ... to relieve the honest debtor from the weight of oppressive indebtedness and permit him to start afresh free from the obligations 
With the role of creditor in this country becoming increasingly concentrated in a few large credit card companies, the politics of bankruptcy are shifting. The appeal of providing a fresh start to the hard-working bankrupt is undeniable. Accordingly, to promote a radical recasting of the bankruptcy laws in their favor, the credit card companies have sought to shift attention from the first of the three moral questions described above, protecting the innocent from hardship, to the third, distinguishing the innocent from the blameworthy. Thus, while not challenging the premise of granting relief to the innocent, they have sought to define more narrowly who really is innocent. Leading with proposals that purport to impose tougher standards on willfully "deadbeat" debtors, the credit card industry has succeeded in winning wide bipartisan support for a package that would severely undermine the "fresh start" offered to numerous bankrupts falling well within traditional definitions of worthiness-bankrupts whose debt cannot fairly be ascribed to moral turpitude. ${ }^{75}$

2. Restructuring Value-Neutral Legal Systems to Impose New Tests of Moral Virtue. - Perhaps the new moralizers' most aggressive project has been not their judgments of behavior already present in society but their increasing tendency to construct new challenges that individuals must surmount to establish their moral virtue. 1t is here-by seeking to compel contests even among those ill equipped to compete, and by placing high stakes on the outcomes of those contests-that the new moralizers most open themselves to charges of reviving a kind of social Darwinism.

Forcing individuals to affirmatively prove their morality is a far more active role than government typically has played. Indeed, many legal rules deliberately seek to avoid imposing difficult ethical dilemmas. The privilege against compulsory self-incrimination reflects in part the realization that basically decent people might be tempted to perjure themselves if the alternatives are a criminal conviction and a citation for contempt of

and responsibilities consequent upon business misfortunes." Williams v. United States Fid. \& Guar. Co., 236 U.S. 549, 554-55 (1915).

75. H.R. 975, 108th Cong. $\$ 302$ (2003) (establishing rebuttable presumption that bankruptcy petition is filed in bad faith if a prior petition was dismissed within the previous year for reasons that may include the debtor's procedural errors or inability to make payments); see Nat'l Consumer Law Ctr., What's Wrong with H.R. 975, Let Us Count the Ways ... (2003), at http://www.nclc.org/initiatives/bankruptcy/content/hr975_content. $\mathrm{html}$ (on file with the Columbia Law Review). Responding far more energetically than they did in opposition to the 1996 welfare or immigration laws, the proconsumer minority opposing the credit card industry seized upon emotionally charged issues of their own: affluent people declaring bankruptcy while retaining mansions, and violent antiabortion demonstrators wreaking havoc and then escaping liability through bankruptcy. None of these groups - the craven bankruptcy junkies of the credit card industry's propaganda, the affluent who game bankruptcy laws, nor bankruptcy-savvy clinic blockers-represent more than a trivial fraction of the population whom the bankruptcy bill's core provisions would affect. Nonetheless, the emotional strength of these images gave both the consumer advocates and the credit card industry cover for their essentially unrelated positions on the underlying legislation. 
court. Similarly, the spousal testimonial privilege recognizes that some honorable people might choose to perjure themselves rather than incriminate their spouses or go to jail for contempt. We refuse to convict people of crimes they indisputably committed if a government agent planted the idea for the crime in their minds. ${ }^{76}$ We warn people applying for government benefits that their statements will be verified, and that falsehoods will be punished severely, to help them resist any temptation to exaggerate. ${ }^{77}$

We thus temper our judgments of choices people make under trying circumstances. In fact, when two choices are involved-an initial choice to put oneself in a position where a second, difficult choice would have to be made-we tend to scrutinize that first choice more closely. The fact that one's drunkenness prevented him or her from forming a culpable intent to injure provides no absolution if the individual voluntarily consumed alcohol. ${ }^{78}$ The fact that a surgeon did the best that she or he could in a difficult operation is no defense if the surgeon should have recognized that she or he lacked the necessary skills. ${ }^{79}$

The new moralizers, on the other hand, have been quite willing to have the government put people to the test. Commonly, these tests involve holding people strictly responsible for difficult choices they made in situations where those individuals may not have wanted to make any choice in the first place. In other words, they had a choice, but they had no choice about whether they would be thrust into the position of having to make that choice. ${ }^{80}$

A broad range of social policies could be seen as falling under this rubric. When we underfund schools in low-income areas, it is difficult to say that many of the students that left those schools with poor job skills chose to need public assistance. A more active version of this approach is the movement to foreclose litigation by managed-care patients. To be sure, those patients typically chose their particular managed-care plans (and perhaps their assigned gatekeepers). Yet those choices are unlikely to be terribly well informed, particularly if they have not been told about, or lack the sophistication to understand, the plan's risk-sharing and medical approval policies. More broadly, the very choice of being in managed care, rather than in a fee-for-service arrangement in which their physi-

76. See, e.g., Sherman v. United States, 356 U.S. 369, 375-76 (1958) (overturning conviction where informant working for the government induced offender to commit crime).

77. See, e.g., 7 C.F.R. $\$ 273.2$ (b) (1) (2002) (requiring warnings on food stamp applications).

78. Model Penal Code $\$ 2.08$ (1962).

79. See, e.g., Johnson by Adler v. Kokemoor, 545 N.W.2d 495, 508-09 (Wis. 1996) (holding admissible evidence that surgeon exaggerated previous surgical experience when seeking plaintiff's informed consent to perform surgery).

80. This approach is perhaps a distant cousin to the enforcement of contracts of adhesion and the doctrine of assumption of the risk: holding unfortunate, effectively powerless people accountable for apparent choices that were not in fact voluntary. 
cians' interests are more likely to align with their own, is increasingly being forced upon patients.

PRWORA's work rules offer another application of this approach, as well as a marked departure from previous work programs, which sought to improve participants' employability. Some of those programs demanded unpaid work ("workfare"), but most involved either job searches-seeking immediate employment-or classes teaching job search techniques or marketable skills. Recipients for whom participation was likely to involve extreme hardship (e.g., those caring for small children or ailing relatives) were spared the difficult decisions. PRWORA, by contrast, shows little interest in any constructive, instrumental purpose for its work requirements. Indeed, states are sharply limited in their ability to assign recipients to job search programs, job search training programs, or skills classes. ${ }^{81}$ Thus, the work requirements exist primarily as a moral test for recipients. Indeed, PRWORA makes this test rather merciless by offering no exemptions for recipients caring for relatives with disabilities and none for those caring for small children unless they can demonstrate the unavailability of child care. ${ }^{82}$

The dual definition of the term "work requirement" nicely illustrates the shift from individualized adjudication to per se tests of virtue. Historically, "work requirements" in Aid to Families with Dependent Children (AFDC), general assistance, and food stamps authorized administering agencies to assign claimants to work-related activities and to sanction those who did not comply. Some claimants did not get or understand the notices and were sanctioned as a result. Nevertheless, in principle, sanctions depended on whether the claimant complied with this specific requirement or, if not, whether she or he had compelling reasons for not doing so. The "work requirement" PRWORA added to the Food Stamp Act for childless adults, ${ }^{83}$ on the other hand, punished the mere status of being unemployed or underemployed. PRWORA's work requirement cut off benefits after three months to those not working twenty hours per week, whether or not the claimants were willing to work and seeking em-

81. See 7 U.S.C. $\S 2015(0)(1)(C)$ (2000); 42 U.S.C. $\$ 607(c)(1)(A),(c)(1)(B)(i)$, (c) (2) (A) (i), (c) (2) (D) (2000).

82. 42 U.S.C. $\$ 607(\mathrm{e})(2)$. The paucity of federal exemptions from work requirements under the Temporary Assistance for Needy Families (TANF) block grant is difficult to understand as deference to states' discretion. PRWORA did set work participation rates that allowed states to create their own exemptions, and many have done so at least for parents of the youngest children. See id. $\$ 607$ (c)(1)(A). The legislation's work participation rates, however, were intended to limit sharply the number of exemptions states could provide, particularly since some recipients inevitably will not be able to participate for enough hours to qualify during their first and last months on the program and in months when they are in transition from one work program to another. The unexpectedly dramatic impact of PRWORA's caseload reduction credit did give states far more flexibility in this area than expected, but pending TANF reauthorization legislation would tighten those participation rates to the point that states will be far less able to exempt recipients from work requirements.

83. 7 U.S.C. $\$ 2015(0)$. 
ployment. This provision's sponsors argued on the House floor that those unable to find work could "do workfare," 84 but imposed no requirement that states operate such programs, much less offer an opportunity to work for benefits to each childless adult who had been in the program for three months. In fact, only a tiny handful of states had such programs for childless food stamp recipients in $1996 ;{ }^{85}$ despite substantial financial incentives, ${ }^{86}$ most have been unwilling to establish programs that would assure claimants a chance to "do workfare" in lieu of being cut off. Repeated efforts to extend the three month cut-off, or to exempt those looking for work or those willing to work off their benefits, have failed as members of both parties did not want to be perceived as relaxing the treatment of people who are not complying with "work requirements." Time limits on cash assistance similarly have been mischaracterized as targeting those unwilling to work, albeit not in statutory language.

The most dramatic application of this approach, however, involves proposals to convert some or all of Social Security into individual accounts. The parallels with the welfare debates of the 1990s are striking. The design of an income security system for elderly, disabled, and bereaved persons, like the design of welfare and the other social policies discussed in this Essay, depends on how society answers variants of the three basic moral questions advanced at the outset. First, how much protection do people deserve against the effects of having received low wages through much of their working lives (or the effects of having depended upon a low-wage worker for support)? Second, how mucb protection do people deserve against the effects of their own bad decisions (and those of persons on whom they depended for support)? And third, what constitutes a bad decision? 87

The present system implies relatively few judgments about the decisionmaking of claimants and thus revolves around the first question, protecting those unable to work from innocent hardship. However well or poorly a former worker may have spent or invested her or his earnings will affect the outside income and financial reserves available to that retiree and her or his family. The worker is not, however, asked to invest

84. 142 Cong. Rec. H7905 (daily ed. July 18, 1996) (remarks of Rep. Kasich).

85. Ctr. on Budget \& Policy Priorities, Food Stamp Provisions of Welfare Law May Have Harsher Effect on Unemployed Adults Than Congress 1ntended 2 (1996).

86. See Food Stamp Program: Food Stamp Provisions of the Balanced Budget Act of 1997, 64 Fed. Reg. 48,246, 48,252-53 (Sept. 3, 1999) (waiving limits on the amount a state may be reimbursed per slot if the state promises to offer a work slot to every claimant that would be denied benefits without one); David A. Super, The Quiet "Welfare" Revolution: Resurrecting the Food Stamp Program in the Wake of the 1996 Welfare Law, 79 N.Y.U. L. Rev. 1271, 1345-47, 1391-93 (2004) [hereinafter Super, Quiet Revolution] (describing the political process that led states to decline to offer needy people the opportunity to work for continued food stamp benefits).

87. As in the case of programs for low-income families, a host of subsidiary, but important, administrative questions abound, including those concerning the financing of interventions and the scope of the federal government's responsibility for operating the system. 
her or his Social Security taxes and thus will receive the same benefits whatever her or his financial acumen may be.

In Social Security policy, as in welfare policy, the basic thrust of the new moralizers' program has been to expand individual choice, with punishments attaching to choices judged to be wrong. Just as they had sought to divide welfare recipients between the work ready and the slothful, and between the chaste and the promiscuous, the new moralizers' proposals for Social Security would divide retirees (and their dependents) between the savvy investors and the naive. ${ }^{88}$ Although we may not stigmatize poor investment decisions to the same extent we do sloth, the effect is similar: The individual loses her or his claim for society's help with her or his misfortune. Just as the new moralizers' position in the welfare debate had little patience for low-income people unable to function effectively in the world of work, new moralizers now appear unimpressed with those who make poor investments because they are unable to understand the complexities of the financial world. ${ }^{89}$ The administrative costs of maintaining individual investment accounts for all workers and retirees would be staggering-just as high administrative costs have long been the prime deterrent to the growth of workfare programs-but the new moralizers are unfazed. To them, apparently, the importance of setting up the means for individual choice, and hence for dividing beneficiaries into the virtuous and the flawed, is the overriding value.

88. The net effect here is to import a division between the "worthy" and "unworthy" elderly into Social Security, resembling the old view that the elderly poor were suffering from the effects of indolence or profligacy during their working years. That approach, however, essentially judged a segment of the elderly based solely on the status of being poor. This new moralizer approach is likely to be more sustainable because it bases its stigma and its consequences on investment decisions that the elderly actually made, albeit decisions that many did not wish to make.

89. It is difficult to justify converting part or all of Social Security into individual accounts that must be invested by claiming that such a plan imposes fiscal discipline and prevents financially prudent retirees from having to pay for the retirements of those who made poor investments. The current system avoids this problem by not forcing people to make complex, difficult investment decisions in order to secure their retirements. If all the new moralizers wished to do was avoid paying for other people's bad investment decisions, they need do nothing more than keep the current system in place. The transitional costs necessary to convert to an individual account system while paying benefits to those already retired or soon to do so are of a similar order of magnitude to the amount of subsidies required to maintain the current benefit structure. See Peter A. Diamond \& Peter R. Orszag, Ctr. on Budget \& Policy Priorities \& The Century Found., Reducing Benefits and Subsidizing Individual Accounts: An Analysis of the Plans Proposed by the President's Commission to Strengthen Social Security 31-33 (2002), available at http:// www.cbpp.org/6-18-02socsec.pdf (on file with the Columbia Law Review) (demonstrating that the same general revenue transfers required to finance individual accounts in a privatized Social Security system could fund considerably higher benefits under the current system); see also Henry J. Aaron \& Robert D. Reischauer, Countdown To Reform: The Great Social Security Debate 76-78 (rev. ed. 2001) (discussing the extent of the transition problem). 
In Social Security policy, as in the welfare debate, virtually all public and media attention has focused on new moralizers' proposals for a short-term system that is almost certainly unstable, with little attention to where that ultimately may lead. The federal funding commitment to the Temporary Assistance for Needy Families (TANF) block grant that replaced AFDC is likely to erode over time, with family income security becoming increasingly a state or local responsibility. Similarly, a system of mandatory individual accounts coupled with a continued social insurance component is unlikely to prove a sustainable long-term vision for Social Security. If retirees and their dependents can be penalized for making poor investment decisions with money in mandatory accounts, it is a short step to penalizing them for the profligacy of declining to invest adequate amounts outside the Social Security system. Also, the competition with individual accounts is likely to make the rate of return of the remaining social insurance component of the program look still more unappealing, particularly for more affluent workers, thus creating dual pressures on defenders of the social insurance remnant. In the short term, increasing the system's political viability may require reducing its current redistributive features, thus threatening to impoverish persons retiring from lowwage jobs, as well as survivors and disabled workers. In the long term, this policy creates possibly irresistible pressure to give workers an option to invest all, or almost all, of their payroll taxes in individual accounts, which would destroy completely the redistributive nature of Social Security.

Defenders of Social Security, like advocates for the poor, have relied too much on negative messages to sustain their program. Progressives lost the welfare debate because, for too long, they took for granted the public's basic sympathy with their values and their belief that income security programs were a moral necessity. By the time they realized that the social and political consensus of the I970s had evaporated, it was too late. In much the same way, defenders of Social Security made it the "third rail" of American politics while doing little to build public awareness of how the system works and what it accomplishes. The public thus is ill equipped to evaluate the severity of the system's actuarial imbalances, much less to appreciate the corrosive nature of the new moralizers' proposals to transform it.

The new moralizers are increasingly applying the philosophy that has guided their welfare and Social Security initiatives to other public policy arenas, including ones where they are attacking a moral consensus of far more recent vintage. A good example is healthcare. By the early 1990s, a wide segment of swing voters had come to see this issue in terms of the first of the basic moral questions, concluding that people should not suffer or die from treatable illnesses due to the innocent misfortune of the lack of healthcare coverage. ${ }^{90}$ Governors and some members of Con-

90. See Weaver, supra note 18 , at 172-75 (finding that, while the public generally opposes spending more on "welfare," support for spending more on "assistance to the 
gress won elections campaigning on promises to broaden the availability of health insurance.

In the near term, technical problems with particular healthcare reform proposals-inept design and disastrous marketing-submerged this issue on the national level. In particular, the all-too-aptly named "catastrophic" healthcare legislation enacted in $1988^{\circ 1}$ (and quickly repealed ${ }^{92}$ ) buried the concept of Medicare expansion for over a decade. The labyrinthian Clinton plan of 1993-1994 banished national healthcare reform from the national agenda for at least as long. As these proposals were failing on technical grounds, however, the goal of universal or near-universal coverage was nonetheless accepted across most of the political spectrum. The leading Republican healthcare reform plans offered far-reaching expansions of government's role in making health insurance available to low-income people. After national healthcare reform failed, numerous states adopted significant initiatives to reduce the ranks of the uninsured. The state budget crises, beginning in the recession of 2001, forced numerous states to roll back these efforts, but again the problem was technical, not philosophical: Governors and state legislators expressed regret for the Medicaid cuts they made.

These design and funding issues, by themselves, are unlikely to prevent a broad expansion of publicly funded health coverage. Enough of the public has come to accept the importance of universal healthcare coverage that this issue is bound to resurface. Indeed, private employers' ongoing reductions in health benefits guarantee this issue continued prominence. Unless new moralizers can reframe the issue-to shift the debate away from the relief of innocent suffering-the result is likely to be a broad expansion of the government's role in providing health insurance. That, in turn, will give the government a strong stake in controlling healthcare costs, likely leading to increased regulatory involvement. Simple economic conservative arguments about limited government and deference to the free market no longer suffice to defeat this humanitarian impulse.

Yet in this area as well, the new moralizers have advanced a steady stream of legislation seeking to redefine the issue as one of individual morality. Promoting tax-preferred medical savings accounts (MSAs) or Health Savings Accounts (HSAs) and tax credits for the purchase of individual health insurance policies shifts the focus to the individual. Instead of being faultless victims of a malfunctioning healthcare system, the uninsured can be portrayed as imprudent spendthrifts that failed to take the necessary precautions. Alternatively, seriously ill individuals who have ac-

poor" has consistently exceeded support for reducing such aid by margins of forty percentage points).

91. Medicare Catastrophic Coverage Act of 1988, Pub. L. No. 100-360, 102 Stat. 683 (repealed 1989).

92. Medicare Catastrophic Coverage Repeal Act of 1989, Pub. L. No. 101-234, 103 Stat. 1979. 
counts but postponed care can be blamed for their bad decisions--even if they delayed for reasons of financial insecurity. ${ }^{93}$ The 2003 Medicare prescription drug legislation thus includes a massive new HSA initiative that offers employers substantial incentives to shift their healthcare coverage to relatively inexpensive plans with high deductibles. ${ }^{94}$

Liberal technicians can argue that MSAs, HSAs, and individual health insurance policies are not financially feasible for many of the uninsured, and that the individualized purchase of health insurance will lead to adverse selection-destabilizing the health insurance market and making healthcare coverage even less available to low-income people and those with serious illnesses. Few members of the public, however, are equipped to evaluate these complex economic arguments. Many also may have difficulty identifying with people who cannot afford to save and for whom purchasing insurance means forgoing other necessities. ${ }^{95}$ The moral argument presenting uninsuredness as blameworthy is far easier to digest. Thus, the new moralizers are well on their way to shifting the debate from the first moral question to the third in the healthcare arena just as they are in Social Security.

3. Replacing Broad Rules Regulating Elites with Tests of Moral Culpability. - At the same time the new moralizers were imposing per se rules in place of individualized determinations of the culpability of politically weak groups, they were doing very much the opposite with elites. They replaced general proactive industrial regulation with policies that require an individualized determination of culpability to take effect. Again and again, we are told that a broad, largely honorable group should not be restricted just because of the bad behavior of a few unscrupulous individuals. Here, as in their treatment of politically unpopular groups, the new moralizers take advantage of, and seek to accentuate, the middle-class public's preconceptions about who is likely to be morally culpable and that public's failure to comprehend fully the circumstances of those being judged. But where many middle-class people may fail to understand exculpatory information about marginal groups (e.g., the trouble a lowskill mother had keeping a job through frequent child care crises or the

93. The effort to cast patients as consumers engaging in routine commercial transactions for which they should be held accountable is prohlematic for a number of reasons, most ohviously because patients must depend on physicians and other healthcare providers in ways that consumers in other markets need not rely upon their vendors. See, e.g., Paul Starr, The Social Transformation of American Medicine 225-27 (1982) (descrihing the failures of the American healthcare market).

94. See Robert Greenstein \& Edwin Park, Ctr. on Budget \& Policy Priorities, Health Savings Accounts in Final Medicare Conference Agreement Pose Threats Both to LongTerm Fiscal Policy and to the Employer-Based Health Insurance System 3-4 (2003), available at http://www.cbpp.org/10-27-03health.pdf (on file with the Columbia Law Review) [hereinafter Greenstein \& Park, Health Savings Accounts] (finding that legislation would encourage employers to reduce or eliminate coverage provided to their employees).

95. This outcome is particularly likely if they are told that some version of Medicaid provides for low-income people and that healthcare professionals and institutions still provide extensive "charity care." 
difficulty a victim of foreign oppression may have navigating the U.S. immigration bureaucracy), their ignorance of elites may cause inculpatory information (e.g., the availability of consultants to identify and correct violations before government inspectors appear) to go unnoticed. Moreover, the new moralizers have reduced further the number of persons found morally blameworthy-and hence the importance of the third moral question as applied to elites-by making the tests costly for agencies to apply. Thus, while members of disfavored groups are subjected to easy-to-apply standards of purported morality that they would have difficulty passing, those presumed to be virtuous are subject to morality tests that agencies can afford to apply only rarely and that are easy for the elite individuals to pass. ${ }^{96}$

This Part examines the new moralizers' tandem efforts to make the regulation of elites depend on determinations of moral blameworthiness and to minimize the number of such determinations that occur. Part II.A.3.a illustrates this process with specific examples in a variety of regulatory contexts. Part II.A.3.b then analyzes the assumptions implicit in this approach.

a. Applications of the New Moralizing to Trusted Elites. - In some respects, the new moralizers' efforts to narrow the application of environmental, health and safety, and other regnlations on business are not new. Conservatives long have argued for an antitrust policy that does not assume big is necessarily bad.

A prototype for this strategy can be seen in debates over gun controls. Instead of controls on all firearms of a particularly dangerous design, gun enthusiasts have argued that convicted felons should be banned from owning any guns. This hardly solves the problem: Avoiding a felony conviction is hardly an adequate measure of whether someone can safely be entrusted with the power of life and death. Some very careless people, who might fire a gun accidentally or leave it within reach of children, are not felons. Nonetheless, the National Rifle Association and its allies have sought to focus on moral blameworthiness, rather that the availability of guns, as the source of danger.

The new moralizers have applied a similar approach to a wide range of other issues. We are told that our problem is individual corrupt politicians, not a system in which all but the richest candidates are heavily de-

96. Although this has become a cornerstone of the new moralizers' social policy, liberals have occasionally tried something similar. David Ellwood proposed to time-limit the cash-assistance benefits that low-income people could receive as part of a complex and expensive plan to increase supportive services-and to provide public employment for those reaching the time limit. David T. Ellwood, Poor Support 121-27, 178-85 (1988). Ellwood surmised that, with adequate supportive services and supplemental benefits, few families would reach the time limits. This attempt proved disastrous for the families Ellwood sought to help. First Bill Clinton, and then congressional Republicans, abandoned the promise of supportive services and johs of last resort while retaining his time limit concept. Particularly without the supportive services, the time limit proved a very difficult test for welfare recipients to pass. 
pendent on wealthy donors to get their messages out. ${ }^{97}$ The powerful financial incentives for accounting firms to please their clients are discounted; we are assured that most accounting and corporate executives have the moral fiber to ignore these incentives. ${ }^{98}$ Congressional Republicans have advanced legislation that would allow a company to sponsor "investment advisers" to advise its employees on managing their $401(\mathrm{k})$ pension accounts-despite the obvious incentive these advisors would have to promote the company's stock; the legislation purports to respond by raising the penalties for failing to provide certain statements. ${ }^{99}$ Arguments for the proposed Family Time Flexibility Act, ${ }^{100}$ which would allow employers to offer future time off in lieu of premium wages as compensation for overtime work, are premised on the assumption that employers will not coerce their workers into waiving overtime pay for undesired compensatory time or at least that the opportunity for workers to sue resolves any problem of coercion. In each of these cases, we are asked to trust that elites will act in an economically irrational manner out of moral rectitude and to design public policies to focus only on those who do not. Yet proving that a public official has been bribed, that an accountant has cooked the books, that an investment advisor has shilled in bad faith for management, or that a boss has subtly pressured a worker is all but impos-

97. When Business Week asked House Majority Leader Tom DeLay about a provision he and other leading Republicans inserted in energy legislation to exempt a major political donor from securities regulation, he responded:

It never ceases to amaze me that in this town people are so cynical that they want to attach money to issues, money to a bill, money to amendments. They hardly ever write that money is given to support people who think the same way. Westar supported people who were doing the things they believed in and wanted to see done. Sure, there may have been elected officials who tie money to their actions. [But] most members are here to do the things that people sent us here to do. We believe in what we're doing, and money has no influence on it whatsoever.

Patricia O'Connell, Q\&A with Tom DeLay, BusinessWeek Online, June 30, 2003, at http:// www.businessweek.com/magazine/content/03_26/b3839091.htm (on file with the Columbia Law Review).

98. Among those contesting this approach was Paul Sarbanes, the liberal Democratic Chairman of the Senate Banking Committee:

"The president and others [want] to punish the 'bad apples," [Senator] Sarbanes [D-MD] said. And while saying he supports that action, that is no substitute for a strong statutory framework to prevent bad behavior from the outset, Sarbanes added. "We have to make sure the gatekeepers are doing their job," Sarbanes said.

Pamela Barnett, Finance: Sarbanes Says Punishing 'Bad Actors' Not Enough, National Journal CongressDaily, July 8, 2002, at http://nationaljournal.com/cgi-bin/ifetch4?ENG+ CONGRESS+7-cd0097+11092 14-REVERSE+0+0+26715+F+1+2+1§arbanes+AND+PD\%2f07 \%2f08\%2f2002\%2d\%3e07\%2f08\%2f2002 (on file with the Columbia Law Review).

99. National Employee Savings and Trust Equity Guarantee Act of 2004, S. 2424, 108th Cong. $\$ 204$ (allowing companies to sponsor advisors without liability); id. $\$ \$ 102$, 201 (imposing penalties for failure to provide statements to plan participants).

100. H.R. 1119, 108th Cong. (2003); see also Family Time and Workplace Flexibility Act, S. 317, 108th Cong. (2003). 
sible-and by the time malfeasance can be proven, the damage may be very difficult to repair.

Limiting the law's sanctions to bear on members of trusted elites only when a particular individual is found morally blameworthy not only ignores existing problematic incentives but also can eviscerate efforts to create new ones to deter harmful actions. Even before the new moralizers changed its enforcement policy, the Occupational Safety and Health Administration (OSHA) had such limited resources for inspections that it had questionable ability to deter misconduct. ${ }^{101}$ Directing inspectors to work with employers to correct hazards before writing citations all but eliminates employers' incentives to monitor the safety of their workplaces absent an OSHA inspection. The new moralizers similarly have sought to limit environmental enforcement to polluters that conclusively demonstrate their blameworthiness by persisting after a warning from government inspectors. ${ }^{102}$

Understanding the shortcomings of this approach requires technical knowledge the public lacks: the number of workplaces or potential polluters to be inspected, the number of inspectors available, and the average time required to travel to and inspect a site. It also requires seeing corporate managers' behavior as neither wholly benign nor wholly wicked: willing to respond to incentives but under enough other pressures that they will not take the initiative to hire consultants to search out problems before an inspection if they can wait for an inspector to do it for them. ${ }^{103}$

Appeals to the supposed indomitable ethical standards of business leaders have even extended to situations in which no real system of sanctions exists to deal with the behavior of the "deviant" executive. ${ }^{104}$ Suc-

101. See Lily Whiteman, Ignored Lessons from Petrochemical, Construction, and Grain Handling Disasters: The Case for a National Industrial Safety Board, 2 Wis. Envtl. L.J. 47, 93 (1995) (noting that OSHA has "insufficient resources to make regular inspections" and has "levied insufficient fines and penalties to serve a deterrent purpose").

102. See, e.g., Clifford Rechtschaffen, Deterrence vs. Cooperation and the Evolving Theory of Environmental Enforcement, 71 S. Cal. L. Rev. 1181 (1997) (critically examining movement toward cooperative-oriented methods of achieving compliance with environmental laws).

103. These enforcement procedures are justified in part by assertions that OSHA regulations are overly prescriptive, that it is disproportionate, for example, to sanction an employer for failing to post required notices. Had the new moralizers proposed to repeal requirements they found offensive, the technical merits of these requirements could be debated and weighed transparently against the imposition on employers. By freeing employers from any obligation to comply until specifically ordered to do so by an inspector, and leaving OSHA's enforcement staff so underfunded that inspections would be exceedingly rare, however, these changes effectively repealed all regulations to which they applied without any debate on their merits.

I04. A classic example of the dangers of assuming that ethical standards are selfexecuting is S.E.C. v. National Student Marketing, Corp., 457 F. Supp. 682 (D.D.C. 1978), in which the court declined to enjoin two large law firms from practicing securities law on the grounds that their status as officers of the court would guarantee that they would behave responsibly. Not long afterwards, one of the defendants paid twenty-four million 
cessive rounds of legislation over the past few years have sought to weaken or eliminate requirements that companies provide pensions to lower-paid employees on terms at least broadly analogous to tbose offered to their top executives if they are to receive certain tax preferences. ${ }^{105}$ The proponents of this legislation justify it as a paperwork reduction measure that will make it easier for more employers to offer pensions. Objections that the legislation will allow companies to shift pension resources to their best-paid employees at the expense of those that need them most are treated as slanders on the corporate managers involved. Similarly, opposition to the recent relaxation of rules against coownership of media outlets serving the same market likely is being blunted by the assumption that the resulting conglomerates will continue traditions of journalistic independence-even though the rule offers no meaningful recourse should that not prove to be the case.

Taking to heart Chief Justice Marshall's view that "the power to tax involves the power to destroy," 106 the new moralizers have begun to recast tax policy in terms of the determination of moral blameworthiness. By portraying taxes as penalties on conduct, they can argue that blameless conduct should be exempted from taxation. New moralizers have applied this rhetoric most fervently to the repeal of the estate tax, with House Majority Leader Tom DeLay calling it "the most evil tax on the books." 107 Since neither dying nor seeking to provide for one's survivors are immoral acts, if the new moralizers' premise on the role of taxation is granted then the estate tax would be illegitimate. Similarly, President Bush has argued for the repeal of the taxation of dividends. If taxes truly were penalties, he too would have a persuasive point: Few would want to punish the act of investing. Of course, taken to its logical extreme, this argument would transform the national government into an oversized justice of the peace, surviving on whatever penalties it could extract from malefactors. Yet the selectivity of this approach to moralizing is difficult for the public to grasp. Exempting virtuous decedents and investors from taxation shifts a greater proportion of taxation onto wages and salaries; few would argue that working should be penalized. The new moralizers' response, a neat fusion of economic conservatism and the Protestant virtue of thrift, is a regressive tax on consumption.

b. The Assumptions Underlying the New Moralizers' Treatment of Problematic Behavior by Members of Elite Groups. - The success of the new moralizers' arguments depends upon a view of the world in which bad events flow only from individuals' personal immorality or from the unavoidable

dollars to settle another securities fraud claim. Geoffrey C. Hazard, Jr. et al., Law and Ethics of Lawyering 117 (3d ed. 1999).

105. See, e.g., Economic Growth and Tax Relief Reconciliation Act of 2001, tit. VI, Pub. L. No. 107-16, 115 Stat. 38, 94; Small Business Job Protection Act of 1996 $\$ \S 1431-1434$, Pub. L. No. 104-188, 110 Stat. 1755, 1802-07.

106. M'Culloch v. Maryland, 17 U.S. (4 Wheat.) 316, 431 (1819).

107. 148 Cong. Rec. H3266 (daily ed. Jan. 23, 2002) (statement of Rep. DeLay). 
forces of nature. In at least three significant respects, this view undermines liberals' (and more traditional conservatives') understanding of when government intervention is appropriate. First, and most directly, this view rejects the concept that problematic results also can flow from poorly designed institutions and incentives misgniding faultless individuals. It thus conflates market failure with moral failure, ignores the effects of bad incentives, and assumes that moral probity is a consistently more powerful force than economic incentives-while at the same time assuming that the actions of those whose ethics it distrusts, such as welfare recipients, reveal their characters rather than the economic incentives they face. Thus, a determination of human fault is necessary before a problem becomes an appropriate subject for a public policy response. ${ }^{108}$

Second, this personalized version of public morality also rejects the concept that adverse effects of human errors can be mitigated or eliminated with better systems. Accidents-from auto collisions to Three Mile Island-are attributed to "human error" rather than to the design of the equipment in question. ${ }^{109}$ This finding then is treated as the end of the inquiry, as if we have found a viable solution: Get humans to stop erring. The inevitability of human error ${ }^{110}$ and malfeasance, and the possibility that systems could avoid putting people into positions where they are likely to err or to fall from grace, are ignored. ${ }^{111}$ Thus, only public policies that address human frailties on an individual level are deemed acceptable.

Finally, this approach depends on its audience's confidence in its ability to assess the rectitude of groups of individuals impressionistically. Groups perceived as upstanding are thus entitled to broad discretion. Congress in 1995 limited the power of the Environmental Protection Agency (EPA) and the Occupational Safety and Health Administration

108. This adds an extra implication to the new moralizers' arguments that we should rely upon voluntary action to address poverty, illiteracy, etc. If we believe that moral people would resolve these problems in their communities, then a simplistic view might hold that the only areas where government intervention is required are those where the more fortunate people are too callous to do their part. That makes government intervention seem quite unappealing, particularly when many of those paying taxes to support that intervention already "gave at the office" through their own voluntary actions. Many well-intentioned people may accept this reasoning, failing to appreciate both the inadequacy of charities' resources to meet the extent of need and the spatial mismatch between affluent potential donors and communities with concentrated need.

109. This insistence that mishaps have but one cause is reminiscent of the fellowservant rule, which denied injured workers recovery from their employer if another employee's negligence was involved-even though the employer also could have averted the injury with a better-designed workplace that gave the fellow servant less chance to err dangerously.

110. See, e.g., Charles Perrow, Normal Accidents: Living with High-Risk Technologies 15-31 (1984) (arguing that the human errors leading to the Three Mile Island accident were inevitable and that, in time, so are errors leading to additional accidents of its kind).

111. Id. at 63-66, 175. 
(OSHA) to regulate any business by invoking small business people, who much of the public likely believes are not inclined to despoil the environment or endanger their employees. ${ }^{12}$

These policies extend presumptions of regularity to the private sector that long have been afforded to public officials. Washington $v$. Davis held that public racial discrimination could not be attacked under the Equal Protection Clause without proof of discriminatory-morally blameworthy-intent. ${ }^{113}$ In City of Los Angeles $v$. Lyons, the Court presumed it was so improbable that police officers would improperly choke persons they were arresting that someone who had been choked during arrest lacked standing to seek an injunction against being improperly choked again. ${ }^{114}$ Evidence obtained in unlawful searches may be admitted in prosecutions if the police acted in good faith. ${ }^{115}$ Superior officials are only liable under $\S 1983^{116}$ for their subordinates' constitutional violations if they acted with "deliberate indifference" to an obvious risk of abuses. ${ }^{117}$ More broadly, the Court has extended immunity to police officers, ${ }^{118}$ prison officials, ${ }^{119}$ and school officials ${ }^{120}$ whose actions, though unconstitutional, are in "good faith" and thus morally faultless. In this latter case, however, the Court rejected the subjective assessments of culpability that new moralizers generally have sought to apply to groups they have favored. ${ }^{121}$ Although the Court has been unwilling to extend this general presumption of legitimacy to private individuals carrying out gov-

112. See, e.g., Timothy F. Malloy, Regulation, Compliance and the Firm, 76 Temp. L. Rev. 451 (2003) (comparing "rational actor" models of corporate compliance with those assuming that corporations strive to comply with the law). Advocates of agricultural subsidies have followed a similar approach for many years, putting the small family farmer's face on programs that primarily benefit large agribusiness corporations. This has contributed to the sharp increase in these programs since the 1994 election even as Congress was cutting spending on food stamps, SSI, and many other programs for lowincome people.

113. 426 U.S. 229,239 (1976).

114. 461 U.S. $95,105-09$ (1983).

115. United States v. Leon, 468 U.S. 897, 906-26 (1984) (permitting introduction of evidence obtained with good-faith belief that search or seizure was pursuant to valid warrant).

116. 42 U.S.C. $\S 1983(2000)$.

117. E.g., Bd. of County Comm'rs v. Brown, 520 U.S. 397, 406-07 (1997); City of Canton v. Harris, 489 U.S. 378, 389-90 (1989).

118. Pierson v. Ray, 386 U.S. 547, 557 (1967) (holding that defense of good faith is available to police officer in actions under $\S 1983$ ).

119. Procunier v. Navarette, 434 U.S. 555, 561-62 (1978) (holding that prison officials are entitled to qualified immunity in $\S 1983$ suits for damages).

120. Wood v. Strickland, 420 U.S. 308, 318-22 (1975) (holding that school board officials are entitled to qualified immunity in suits under $\$ 1983)$.

121. See Harlow v. Fitzgerald, 457 U.S. 800, 816-18 (1982) (setting a doctrine of "good faith" immunity for public officials but defining "good faith" not in terms of the state of mind of the official but in terms of "rigbts of which a reasonable person would have known"). 
ernmental functions, ${ }^{122}$ the new moralizers are in the process of doing so piecemeal.

\section{B. Harsher Measures Against Those Deemed Unworthy}

Reorienting the law's treatment of the question of what is morally culpable, as discussed above, has been the new moralizers' foremost theme. One obvious consequence of the proliferation of rules finding individuals morally blameworthy has been to increase the importance of the second question identified at the outset of this Essay: What hardship should society allow, or require, people to suffer for their moral faults? To shift debate further from the question about what society should do to relieve innocent suffering, the new moralizers have made an issue of what they consider excessively lenient treatment of those that are found unworthy. In the process, they have executed a neat reversal of history. In the past, reformers sought to soften the treatment of stigmatized groups in response to doubts about the justice of the stigma and a sense that some basic level of social solidarity is worth protecting. Now, new moralizers demand ever harsher treatment of those determined unworthy and attack anyone calling for moderation as lacking conviction about the importance of the moral judgments being made. Punishments of supposed moral wrongs are no longer limited by practical considerations. The success of this approach has allowed the new moralizers to take the upper hand on a second of the three crucial ethical issues at the core of social policy design while further marginalizing the question of relieving innocent misfortune as fewer and fewer people are recognized as innocent.

Initially, the targets of this regime of harsher punishments have been among the most severely stigmatized in society: prisoners, undocumented immigrants, and welfare recipients. This severe treatment, however, is not limited to those individuals that have in fact been found morally blameworthy, even under the new moralizers' harsh new standards. The Prison Litigation Reform Act (PLRA) does not only punish prisoners convicted of an offense: Even those merely awaiting trial are stripped of important civil rights. ${ }^{123}$ As long as they cause no provable physical injury, for example, jail officials may subject a prisoner to deliberate, methodical psychological torture-threats to loved ones, extreme sensory deprivation, etc.-without fear of suit, even if the prisoner is later found not guilty at trial. ${ }^{124}$ More generally, even if a prisoner manages to navi-

122. See, e.g., Richardson v. McKnight, 521 U.S. 399, 409-12 (1997) (concluding that "private prison guards, unlike those who work directly for the government, do not enjoy immunity from suit in a $\$ 1983$ case"); Wyatt v. Cole, 504 U.S. 158, 168-69 (1992) (holding that private parties do not enjoy immunity from $\$ 1983$ liability for improper garnishment or replevin).

123. 42 U.S.C. $\$ 1997 \mathrm{e}(\mathrm{h})(2000)$.

124. Id. $\$ 1997 \mathrm{e}(\mathrm{e})$. This provision has been applied to reject complaints of dire threats to prisoners' physical health, such as exposure to asbestos. See Fontroy v. Owens, 150 F.3d 239, 244 (3d Cir. 1998); Zehner v. Trigg, 133 F.3d 459, 460-61 (7th Cir. 1997). 
gate the PLRA's obstacle course and proves violations of her or his constitutional or statutory rights, the PLRA provides severe limits on the relief that may be entered on her or his behalf and requires frequent reviews of whether that remedy may be dissolved. ${ }^{125}$ The PLRA also impairs prisoners' already precarious access to legal counsel by limiting the fees that may be awarded to those who navigate its formidable barriers to win civil rights suits. ${ }^{126}$ Prisoners thus are largely set outside the protection of even the minimal laws that nominally apply to them, being denied effective recourse even when their most basic rights are violated. ${ }^{127}$

Similarly, welfare claimants who comply with PRWORA's harsher substantive conditions on the availability of cash assistance, thus proving their worthiness even under the new moralizers' criteria, have lost any individual entitlement to aid. ${ }^{128}$ As a result, a family that is indisputably destitute and that is complying fully with work and other behavioral requirements is to have no recourse if an eligibility worker or local office nonetheless denies it aid arbitrarily. Thus, welfare claimants' rights were not just curtailed to the extent required to achieve the new federal policies: Their rights were gratuitously extinguished altogether. Restrictions Congress imposed on legal services programs in 1995, preventing them from filing class actions or challenging "welfare reform," also contributed to the removal of welfare claimants from the law's protection. ${ }^{129}$ Losing some of what one has been receiving from the state is a common result of the political process; losing all enforceable rights, even to what the majority says one should receive, takes one outside the rule of law altogether.

125. 18 U.S.C. $\$ 3626$ (2000); see also, e.g., Parrish v. Ala. Dep't of Corr., 156 F.3d $1128,1130-31$ (11th Cir. 1998) (dissolving injunction because defendants were not currently out of compliance, thus leaving defendants free to resume the practices that had been enjoined).

126. 42 U.S.C. $\$ 1997 \mathrm{e}(\mathrm{d})$. This provision precludes any serious argument that PLRA's purpose was to eliminate the inefficiencies of poorly pleaded pro se suits and those without legal merit. Representation is likely to improve the efficiency of prisoners' litigation by dissuading prospective plaintiffs from filing clearly meritless cases and by better framing the issues for the court. Since attorneys' fees are awarded only to plaintiffs who have proven a civil rights violation, this provision by definition applies only to prisoners who are not abusing the courts but rather who are themselves being victimized.

127. To the same effect, both PRWORA and IIRIRA override state and local rules that limit individuals wishing to report immigrants-legal or otherwise-to immigration authorities. 8 U.S.C. $\$ \S 1373,1644(2000)$. Thus, even if a state believes that law enforcement, public health concerns, or the need to get aid to relatives of undocumented immigrants make confidentiality necessary, federal law denies the state the ability to promise it. These rules effectively immunize extortion against immigrants in undocumented or other precarious statuses-and against family members that care about them.

128. 42 U.S.C. $\$ 601(\mathrm{~b})$.

129. The prohibition on "welfare reform" litigation was later held unconstitutional, but in the years immediately following PRWORA's enactment, legal services programs could not bring even nonclass lawsuits that challenged "welfare reform." Legal Servs. Corp. v. Velazquez, 531 U.S. 533, 538-39, 549 (2001). 
As in their approach to determinations of blameworthiness, the new moralizers have coupled rhetoric about individual responsibility with per se rules that deny individualized determinations. ${ }^{130}$ In this regard, the new moralizers' approach is similar to that of federal sentencing guidelines that prohibit taking most of an individual's circumstances into account except through extraordinary "departures" that must be explained rigorously. ${ }^{131}$ Indeed, mandatory minimum sentences and the recent "Amber Alert" legislation, prohibiting downward departures from the sentences prescribed in the guidelines for certain kinds of offenses, completely remove individualized assessments from criminal sentencing. ${ }^{132}$ Similarly, PRWORA established mandatory minimum amounts and durations for sanctions for cash assistance ${ }^{133}$ and food stamp ${ }^{134}$ recipients violating behavioral requirements, and AFSA required that states file a petition to terminate parental rights, rather than impose some intrusive but less final sanction, when a child has been in foster care fifteen months.

Presumably part of the justification for denying adjudicators the authority to assess the severity of each individuals' blameworthiness is skepticism that the sentencing judges or administrative staff can accurately make these assessments. This kind of humility about adjudicators' capacity to determine individuals' subjective states of mind is appropriate. It is, however, strikingly inconsistent with the new moralizers' broad agenda of increasing the law's reliance on determinations of individuals' character. ${ }^{135}$

Although this rigid approach to sentencing and sanctioning departs from the largely individualized concept of morality that the new moralizers have advanced, it is quite consistent with their binary concept of morality. If the world is divided between "good" and "bad" people, the search for redeeming characteristics in the latter is ultimately a fool's errand. Moreover, in this binary world, "good" people need not be too concerned with the retribution meted out to the "bad" since the groups are wholly disjoint: Harsh treatments reserved for "bad" people are no more threatening to "good" people than dangerous reptiles are to Greenlanders.

130. Although many valid reasons exist for preferring predictable, rule-based systems in some situations and discretionary decisionmaking in others, see, e.g., Frederick Schauer, Playing by the Rules 222-28 (1991) (examining the role of discretion in dealing with the circumstances that fall between the interstices of existing rules); Duncan Kennedy, Form and Substance in Private Law Adjudication, 89 Harv. L. Rev. 1685, 1685 (1976) (explaining the choice between rules and standards in terms of substantive personal preferences regarding individualism and altruism), the new moralizers' choices here appear highly outcome oriented.

131. U.S. Sentencing Guidelines Manual $\$ \S 5 \mathrm{k} 1.1-5 \mathrm{k} 3.1$ (2003).

132. PROTECT Act of 2003 (Amber Alert) $\S 401$ (a)(2), Pub. L. No. 108-21, 117 Stat. 650,651 (to be codified at 18 U.S.C. $\$ 3553(\mathrm{~b})(2)$ ).

133. 42 U.S.C. $\$ \S 607$ (e) (1), 608(a)(2) (2000).

134. 7 U.S.C. $\S 2015(d)(1)(C)(2000)$.

135. See supra Part II.A.2. 
ln the area of sanction-setting as in that of blame-finding, the new moralizers' treatment of trusted elites operates on premises seemingly irreconcilable with those applied to those less powerful politically. Relying again on the public's inclination to presume the moral rectitude of physicians and businesspeople, the new moralizers have sought to restrict recoveries for malpractice and defective products. ${ }^{136}$ Here, they suggest that an "out-of-control legal system" 137 is too harsh in adjudicating fault as justification for reducing the sanctions for that fault just as their apparent concerns about the leniency of sentencing judges and agency employees led them to impose tough minimum sanctions for fault found in members of other groups.

\section{Deflecting Appeals to Alleviate the Suffering of the Blameless}

Over the past few decades, the first question outlined above-how society should aid its blameless members-has been the most problematic aspect of the ethical public policy debate for conservatives. When liberals assumed worthiness and promoted policies of universal application, they could offer concrete benefits to the electorate; economic conservatives could only offer the abstract values of limited government that the Great Depression had left badly discredited. When promoting policies targeted to those most in need, liberals could appeal to the electorate's most benevolent instincts; in resisting those policies, conservatives tended to sound selfish and unfeeling. ${ }^{138}$ As a result, conservatives have sought to deflect attention from these issues and, when that has proven impossible, have tended to give ground. ${ }^{139}$ Even the leading icon of

136. See, e.g., Bob Herbert, Not So Frivolous, N.Y. Times, June 18, 2004, at A31.

137. See, e.g., Bob Herbert, Cooking Up a Crisis, N.Y. Times, June 25, 2004, at A23.

138. Conservatives' great trump card was the specter of communism: If liherals' regulatory agenda or redistributive programs went too far, they could be accused of perpetrating creeping socialism. See Milton Friedman \& Rose Friedman, Free to Choose: A Personal Statement 286-88, 311 (1980) (asserting that in the early twentieth century, the Socialist Party, with its focus on social responsibility, was "a party of principle," while the major parties were not since they had to avoid "extremism"). Even that argument was undermined, however, by Senator Joseph McCarthy's excesses, by the rise of staunchly anticommunist welfare states in Europe, and by the increasing realization that the Soviet Union was far too repulsive to serve as a plausible model for most thoughtful people. Also, to the extent some people believed this country was in ideological, as opposed to military and diplomatic, competition with the Soviet Union, they might have been concerned that too much hardship in this country would play into the hands of Soviet propagandists. Trattner, supra note 9 , at 314. In any event, the collapse of European communism robbed conservatives of the emotional trump card they held for most of the century and left them with rigorous but emotionally uninspiring arguments for preserving free markets.

139. Thus Richard M. Nixon, regarded as a conservative Republican in his day, signed legislation taking the food stamp program nationwide, assuming federal responsibility to provide income security for the low-income elderly and disabled at substantially increased levels, regulating land use in coastal zones, creating the Environmental Protection Agency and the Occupational Safety and Health Administration, and strengthening the Civil Rights Act of 1964, among other things. To be sure, Richard Nixon was an extremely complex President maneuvering in very uncertain political times. See generally John 
modern American conservatism, Ronald Reagan, steadfastly insisted he was preserving a "safety net" for the "truly needy." Indeed, beginning in 1984 he signed into law numerous expansions in means-tested programs, principally Medicaid but also food stamps, the earned income tax credit (EITC), child care subsidies, and others.

Here, too, the new moralizers have found ways to shift the terms of the debate, achieving successes that had eluded economic conservatives. Part II.C.I analyzes how the new moralizers have sought to deflect liberal appeals for greater social interventions on behalf of blameless victims of misfortune. Part II.C.2 then describes the remarkable way in which they have turned this question to their affirmative advantage.

1. Defenses Against Liberal Moral Arguments. - The new moralizers' movement sprang in part from conservatives' fatigue at being labeled hard hearted for their opposition to social spending in the past. A morality that is indifferent to the suffering of blameless members of society would have little appeal. Relying solely on theoretical arguments that "a rising tide lifts all boats" might work with some intellectuals but could seem cold to some of those to whom the moralizers' approach might otherwise have the greatest appeal. Accordingly, the new moralizers needed to have a demonstrable positive component for those whose suffering cannot plausibly be attributed to moral shortcomings. This is the genesis of "compassionate conservatism."

The first President Bush spoke often about "a thousand points of light," his preference for private charity to assume many of the humanitarian burdens public programs had carried in the past. ${ }^{140}$ This slogan, however, was more a celebration of something that was already happening rather than a substantive proposal for the future. Any problem still existing in society presumably had not been resolved by the "points of light"; therefore, this approach was of little value in deflecting proposals for additional governmental interventions. The second President Bush's faith-based initiatives remedied that deficiency by providing a set of affirmative proposals. Because of concerns about church-state entanglement, these proposals were unlikely to be accepted quickly and thus could provide an ongoing alternative to public interventions in a host of difficult areas. To a similar end, the new moralizers' call for expanded tax preferences for charitable contributions provides individualistic out-

David Skrentney, The Ironies of Affirmative Action 177-221 (1996) (describing the social justice policies and politics of the "enigmatic" Richard Nixon and his Administration).

More recently, major Republican healthcare bills in 1993-1994-including those proposed by the party's House and Senate leadership-contained vast expansions of federal regulatory authority and subsidies for low- and moderate-income people. Had it not been for President Clinton's monumental political bungling, these bills would have provided a near-universal guarantee of meaningful health insurance, with the responsibility squarely on the federal government.

140. See, e.g., Points of Light: New Approaches to Ending Welfare Dependency (Tamar Ann Mehuron ed., 1991) (collecting essays from leading social conservatives and others on private sector responses to family poverty). 
lets for the public's humane instincts that may be more satisfying than addressing problems collectively through government interventions. ${ }^{141}$

Indeed, an aggressive program of faultfinding can be married with an apparently generous campaign to help those whose misfortune is deemed blameless. The very process of making judgments about prospective claimants' character can dissuade many from seeking the government's aid, thus thinning the ranks of claimants enough to allow for displays of generosity toward those who do pass the moral test. In Texas, for example, food stamp applicants during the late 1990s were required to be fingerprinted, submit to searches of their homes by badge-waving fraud investigators, and agree to background checks that could suggest to their employers, landlords, neighbors, or children's schools that they were seeking food stamps and were suspected of fraud. ${ }^{142}$ They were required to reapply, and potentially undergo similar scrutiny, every three months. When discrepancies arose, claimants were pressed mercilessly to confess to fraud. Not surprisingly, the decline in Texas's food stamp participation during this period was among the steepest in the country. ${ }^{143}$ This was particularly true among low-income working families, whose income presumably gave them a few more options-and who had to worry about their employers' reactions to calls from state fraud investigators.

Yet at the same time Texas was vigorously scrutinizing the character of claimants, the state was also spending considerable sums on food stamp outreach. Therefore, to those not intimately involved with the food stamp program's antifraud dragnet, Texas appeared to be quite eager to make food assistance available to its low-income population. The state even won several national awards for "customer service" during the very period when it was driving away customers faster than virtually any other state.

To defend themselves against liberals' moral appeals to aid the blameless, new moralizers have pursued several additional approaches. First, they have sought to shift the focus from the relief of innocent hardship by questioning how blameless many of the proposed beneficiaries of public programs really are. The most aggressive polemics in this area have sought to make voters feel that beneficiaries of public programs are taking advantage of society's generous impulses. For example, the bliz-

141. See, e.g., S. 256, 108th Cong. $\$ \S 101-111,139$ A (2003); S. 272, 108th Cong. $\$ \S 101-111,139 \mathrm{~A}(2003)$. These schemes prove inefficient in getting aid to the needy, both because most of their cost goes to subsidize contributions that would have been made anyway and because most contributions go to tax-exempt organizations such as museums and orchestras that do not focus on low-income people. See Joel Friedman \& Robert Greenstein, Ctr. on Budget \& Policy Priorities, Charitable Deduction for Taxpayers Who Do Not Itemize: Proposal Raises Concerns About Effectiveness and Cost 3-5 (2002), available at http://www.cbpp.org/3-21-02tax.pdf (on file with the Columbia Law Review) (discussing the likelihood that proposal will harm poor, as the loss of revenue far outstrips the gain in contributions).

142. Super, Quiet Revolution, supra note 86, at 1312, 1376-78.

143. Id. at 1310. 
zard of stories about food stamp trafficking and about parents coaching their children to "act crazy" to qualify for SSI that led up to passage of the 1996 welfare law were likely to embarrass supporters of those programs. More generally, attacks on the government's competence to meaningfully address problems-attacks that Democrats such as former Vice President Gore have been unable to resist joining-serve a similar purpose. ${ }^{144}$ No one likes to be tricked; if people believe that acting generously will result in feeling foolish, they will be slower to respond to liberals' arguments.

Second, mirroring liberals' response to uncomfortable questions, new moralizers have sought to shift the discussion to technical questions. In particular, they argue where possible that public programs are counterproductive, perversely exacerbating the problems they are set up to address. Whether or not these arguments are valid or persuasive, merely shifting the debate from the moral to the technical is a major victory for the new moralizers. Losing on some technical issue involving the food stamp program's method of calculating households' income sets their agenda back far less than would the acceptance of the principle that people in the United States should not go hungry for the lack of resources to purchase food.

Third, new moralizers can defuse the moral clamor for action by offering the public alternative outlets for its generous impulses. At a time when it slashed more than thirty billion dollars over six years from domestic food assistance programs to help pay for tax cuts, PRWORA also added six hundred million dollars to purchase commodities to distribute through food pantries and soup kitchens. This of course helped to insulate the bill's proponents from criticism that the bill would increase hunger. Another function of that funding, however, is to give volunteers in those emergency feeding organizations something to distribute. Disaster relief similarly provides an alternative outlet for humane, generous instincts. Acute need is both easier to address and traditionally less tinged with moral suspicions than is chronic need. Disasters also affect greater numbers of middle-income people with whom a middle-income electorate can identify more readily.

Finally, exaggerating the extent of the government's existing social interventions can help people feel better about not having it do more. One of the best ways to do this is by ensuring that those spending programs that are created lack entitlement funding and are, in fact, underfunded. ${ }^{145}$ Few members of the public can distinguish between a generous sounding program whose resources allow it to serve only one

144. Jill Lawrence, The Many Sides of Al Gore, USA Today, Aug. 11, 2000, at 4A (describing Gore's appearance on the David Letterman show to smash an ashtray that he presented as symbolic of wasteful government).

145. See David A. Super, The Political Economy of Entitlement, 104 Colum. L. Rev. 633, 696-703, 705 (2004) [hereinafter Super, Entitlement] (describing the public's tendency to assume that nonentitlement programs are better funded than is in fact the case). 
percent of needy claimants and one that is freely available to all those that qualify. Similarly, the news media cover the terms of regulatory laws, not the adequacy of the staff assigned to enforce them. By bitterly complaining about any affirmative action programs, new moralizers likely have convinced the public that those programs are far more pervasive, and far more generous, than is in fact the case. The new moralizers have received considerable help in this effort from liberal politicians who inflate their accomplishments to garner more credit from voters and contributors. When the public hears about numerous, impressive-sounding programs its taxes are funding, and numerous, impressive-sounding regulatory initiatives being undertaken on its behalf, the only reasonable conclusions may seem to be either that the problems are being properly addressed or that the government is incapable of doing so competently. Either way-by relieving the public's sense of moral imperative, by feeding its cynicism, or by forcing liberals to make technical arguments about why existing programs do not suffice but new ones would - the new moralizers can shift the debate to more comfortable terms.

These defensive strategies are not particularly new. President Reagan frequently derided "welfare queens" 146 and Senator Jesse Helms condemned the food stamp program based on anecdotes of apparent misconduct. ${ }^{147}$ More strategically, the Reagan budget cuts of 1981 destabilized AFDC by stripping it of the majority of its most attractive recipients: the working poor. The Reagan Administration also reduced domestic programs' transparency by converting many of them to block grants. ${ }^{148}$ This allowed new moralizers to reduce funding for these programs while still claiming that the federal government was addressing a wide range of social problems. Liberals were then forced to make complex technical arguments that the funding levels were inadequate or that the block grants were being spent inefficiently or diverted to other purposes. The sophistication required to evaluate these arguments largely ensured that they would have little political impact.

2. Affirmative Responses to Arguments for Expanding Relief of Innocent Misfortune. - Where the new moralizers depart from, and advance beyond, their predecessors is in their development of moral arguments allowing them to take the offensive against public policies aiding concededly blameless victims of misfortune. They have done this in two primary ways. First, they have argued that policies aiding one group of innocents would disadvantage another such group. Specifically, they have sought to pit the interests of current innocents against the innocent members of future generations. (Curiously, they favored the latter when addressing government spending programs but the former in their attacks on regula-

146. David Zucchino, Myth of the Welfare Queen 64-65 (1997).

147. See, e.g., S. Rep. No. 97-128, at 172-73 (1981).

148. See Super, Entitlement, supra note 145, at 680-82, 710-11 (pointing out the inefficiency and obfuscation that results from block grant funding). 
tory policy.) And second, they have sought to characterize appeals to relieve blameless misfortune as divisive.

To bring the interests of future generations into opposition with current efforts to relieve innocent suffering, they worked to precipitate a fiscal crisis whose solution would inevitably involve deep cuts in social spending programs. This showed a keen appreciation of the history of the federal budget in the 1980s and early 1990s. Upon taking office, President Reagan initially made a conventional conservative proposal to reduce taxes and spending in tandem. He succeeded in enacting a massive tax cut within a few months of taking office and the first of three promised annual rounds of budget cuts along with part of the second. The recession of 1982, however, along with Republican losses in the 1982 elections, prevented him from completing his plans to reduce domestic spending immediately. Nonetheless, his tax cuts and huge increases in defense spending generated massive deficits that put continuing pressure on the entirety of the budget. This allowed conservatives to argue that reducing, or at the very least, refusing to increase, spending programs was morally necessary to eliminate the deficit. The values of frugality and concern for one's posterity-not leaving future generations with a huge public debt-overrode the altruistic values that supported social spending. In effect, this pitted the interests of one group of innocents, future generations, against another, those currently suffering misfortune. Thus, the new moralizers could claim that they, too, were pursuing a more generous answer to the question about society's duty to relieve innocent victims of misfortune.

This approach did not work flawlessly, and indeed both President Reagan (several times) and the first President Bush (in 1990) agreed to increase taxes, reducing the pressure to shrink government spending. Overall, however, a great many acknowledged domestic problems went unaddressed or received relatively tepid attention. Spending on domestic nonentitlement programs has trended steadily downward, now consuming the lowest share of the economy since the early $1960 \mathrm{~s}$.

Congressional new moralizers in the late 1990s and the second Bush Administration learned from this history and sought to improve upon it. Although the deficits of the 1980s and early 1990 s were to some extent the accidental result of President Reagan's inability to enact the full range of spending cuts he had proposed, recent tax cuts have been proposed without any serious pretense of offsetting savings. By not attempting to pay for tax cuts at the time they are enacted, new moralizers avoid confronting the moral issues that those spending cuts would present. ${ }^{149}$

149. The new moralizers also have suggested that their budget-busting tax cuts benefit another group widely regarded as suffering from innocent misfortune: small-business people. Joel Friedman, Ctr. on Budget \& Policy Priorities, The Administration Tax-Cut Rhetoric and Small Businesses 1 (2004), available at http://www.cbpp.org/9-28-04tax.pdf (on file with the Columbia Law Review) (finding that the Administration's statement tax cuts do much less for small businesses than it claims). 
Once deficit concerns reach the point that they preclude further tax cuts-by which time debt service will be growing rapidly enough to crowd out other spending programs-the new moralizers can revert to being "deficit hawks." 150 Their calls for "fiscal prudence," "shared sacrifice," and "not leaving our children a legacy of debt" will have stronger moral appeal for many swing voters than appeals to aid the unfortunate. ${ }^{151}$

In the regulatory arena, by contrast, the new moralizers have argued that efforts to protect future, anonymous people would cause misfortune to specific people in the present. They argued that insisting on standards to protect the environment, workers' health, consumers, or others destroys jobs. They contended that advocacy for public regulation is not in fact a noble effort to protect future innocents from the loss of natural spaces or injuries. Instead, they argued that these are callous assaults on the livelihoods of innocent, relatively low-wage workers in the present. Their rhetoric in this regard has been quite clever: Advocates of "wise use" cast environmentalists as selfish exclusionists that want to hoard the benefits of a wilderness area for themselves.

More broadly, the new moralizers have sought to stigmatize the very idea of assessing programs' impact on low-income people as "class war-

150. Some liberals appear to believe that the primary purpose of the new moralizers' frenzy of tax cuts is to benefit the wealthy. This is almost certainly mistaken. The overwhelming ideological imperative of the new moralizers is not income redistribution but the evisceration of government, "starv[ing] the beast" in David Stockman's memorable words. Paul Krugman, The Tax-Cut Con, N.Y. Times Magazine, Sept. 14, 2003, at 54. Given the choice, many new moralizers no doubt would prefer to reduce the taxes of the affluent-even though a large part of their electoral base is actually not terribly well off and does relatively poorly under most of the recent tax cuts. But the primary reason for focusing most tax cuts on the affluent is that those groups have been reliable lobbyists for tax cuts. The House showed itself quite willing to provide some benefits for low-income people if doing so provided a vehicle for further evisceration of the federal revenue base in enacting a Medicare prescription drug benefit and in responding to criticism for its failure to accelerate the expansion of the child tax credit. See Robert Greenstein, Ctr. on Budget and Policy Priorities, House Child Credit Legislation Not Fiscally Responsible: Bill More Likely to Harm Children than to Assist Them (June 23, 2003), available at http://www. cbpp.org/6-11-03tax.pdf (on file with the Columbia Law Review) (arguing that legislation accelerating the child tax credit for low-income families was coupled with so many additional extraneous tax cuts that it would deplete revenue base and would ultimately lead to cuts in federal programs for children); Greenstein \& Park, Health Savings Accounts, supra note 94, at 1-3 (arguing that Health Savings Accounts in Medicare prescription drug legislation will mainly benefit those with bigb incomes and starve the federal budget to an even greater degree).

151. Appeals to community spirit also have played a part in producing the fiscal crises that put pressure on social spending. Demands for high defense spending exacerbate those crunches. Altbough forgoing tax cuts could reduce the deficit as easily as spending cuts, new moralizers ask the electorate to choose between the value of preserving the community as a whole-with a strong national defense-and appeals to help a segment of the community. 
fare."152 This epithet makes no sense analytically: If it is divisive "class warfare" to criticize policies that disproportionately benefit one segment of society at the expense of others, surely it is at least as divisive to design those policies in the first place. ${ }^{153}$ Nonetheless, this gambit allows the new moralizers to represent their neglect of social problems not as callousness or selfishness but rather as an affirmation of social cohesion. In a sense, then, the new moralizers suggest that all of us are innocent victims of the loss of community; they seek to relieve this misfortune by rejecting distributional analyses.

\section{The Politics of the New Moralizers}

Having noted the new moralizers' astonishing success in transforming the relationship between law and morality, this Essay now seeks to understand how that success was achieved. Obviously winning a series of congressional elections beginning in 1994 was a necessary condition to many of these triumphs. But it hardly was a sufficient one. Important, too, bas been conservative philanthropy's heavy funding of the development and promotion of ideas, ${ }^{154}$ in contrast to liberals' preference for devoting resources to direct services. Yet the new moralizers have won many of their most important victories with remarkably little opposition, easily gathering the votes of traditional economic conservatives, moderates, and many liberals, along with President Clinton's signature on key pieces of legislation.

This Part examines how other important political groups have related to the new moralizers. Part III.A suggests that, far from mounting a credible opposition, liberals have emulated and thus implicitly ratified some of the new moralizers' key approaches to public policy debates. Liberals have vacillated on whether to respond to the new moralizers with technical or moral arguments and, even when making the latter choice, have failed to articulate a moral vision of sufficient clarity to compete effectively. Part III.B finds that, although the new moralizers' approach to policy analysis rejects basic tenets of economic conservatism, to date the two groups' ends have remained sufficiently similar to allow tbem to form an effective coalition. Part IIl.C argues that the collapse of the non-

152. E.g., Paul Krugman, A Touch of Class, N.Y. Times, Jan. 21, 2003, at A23; Jill Zuckman, GOP Scrambles on Tax Credit: Democrats Blast Law's Exclusion of Low-Income Families, Chi. Trib., June 4, 2003, \$1, at 1 .

153. The particular tax cuts the new moralizers have designed are hardly inevitable. Instead of their reductions in the upper tax brackets and in the taxation on types of income disproportionately received by the affluent, one could for example, increase the personal exemption, a feature of the tax system that affects the vast majority of taxpayers. Even this would benefit the affluent more (due to their higher marginal tax rates), but not to anything like the degree that the actual tax cuts did. One also could increase the standard deduction, advancing the oft-cited goal of simplifying the tax system.

154. See, e.g., Sally Covington, Nat'l Comm. for Responsive Philanthropy, Moving a Public Policy Agenda: The Strategic Philanthropy of Conservative Foundations 31-33, 37-39 (1997). 
ideological technocratic middle that mediated between left and right in prior decades has proven crucial to the rise of a radical movement like the new moralizers. Part III.D seeks to understand why most of the new moralizers' agenda has struck such a responsive chord with much of the public. Finally, Part III.E outlines a strategy for opposing the new moralizers.

\section{A. Liberals' Inadvertent Aid to the New Moralizers}

Although many have been antagonistic to the new moralizers' agenda, liberals unintentionally have provided considerable help to the new moralizers. By exaggerating the extent of programs designed to relieve innocent misfortune, liberals helped the new moralizers argne for a less generous answer to the first question. Suggesting that society had an ample safety net in place also could have persuaded middle-class voters that imposing more moral tests, and dealing more harshly with those who fail them, presents few dangers. Most importantly, liberals undermined their ability to oppose the new moralizers' campaign to make assessments of individuals' moral worthiness as a basis for public policy by seeming to endorse such tests where politically convenient, by seeming indifferent to the moral failings of their leaders and allies, and by exaggerating the reliability of the processes through which assessments of moral character are made.

Some ebullient liberals' tendency toward exaggeration and self-congratulation over their policy successes has played into the new moralizers' hands. If all the social programs that some liberal politicians have congratulated themselves for creating really did all their authors claim, the wellbeing of unfortunate people would be a far less compelling concern. Most obviously, the "War on Poverty" was a worthwhile but hardly transforming set of human services programs: Some were scantily funded in the first place and many were dismantled or dramatically reshaped by subsequent Republican administrations. The memorable rhetoric with which these programs were launched, and liberals' failure to note that the "War" had been canceled, suggested that the government had tried and failed to relieve the suffering of poverty. ${ }^{155}$ The Heritage Founda-

155. See Jon Michaels, Deforming Welfare: How the Dominant Narratives of Devolution and Privatization Subverted Federal Welfare Reform, 34 Seton Hall L. Rev. 573, 583 (2004) (describing conservative social policy changes of 1980 s and 1990 s as reactions to the "unsuccessfully waged War on Poverty"); Super, Entitlement, supra note 145, at 721-25 (describing the sources and consequences of many liberals' affinity for creating numerous underfunded social programs).

In this area, late twentieth-century liberals followed a long tradition of reformers planting the seeds to their own destruction with clearly excessive promises. The founders of asylums for the insane, the impoverished, criminals, and wayward youth offered grandiose promises about the speed and certainty of rehabilitation that would result from the moral interventions they proposed. In doing so, they ignored the intractable problems of chronic mental illness, senility, and hardened career criminals. See Rothman, supra note 18, at 238-39 (describing the pivotal role of these practical problems in the demise of 
tion seized on this opportunity, adding a fabulously inflated price tag for what it called America's "failed war on poverty." 156

In a similar vein, liberals at times have yielded to the temptation to enact social policies for expressive rather than practical purposes. The imperative to "do something" about a serious social problem sometimes has led to meaningful if incremental legislation but, where none was available, also has given rise to symbolic initiatives, some of which have very real undesirable side effects. ${ }^{157}$

Liberals also have provided fodder in several ways for the new moralizers' program of expanding the law's reliance on distinctions between the innocent and the blameworthy. Liberals have been energetic advocates of making an individual's actions, rather than his or her race, gender, or social status, the basis of the law's assessment of moral worthiness. In this venture, they challenged the basis on which the law was making those assessments but not the propriety of judging individuals. Thus, the new moralizers have had little difficulty finding support in the words of revered liberal visionaries. Dr. Martin Luther King, Jr. rallied the civil rights movement behind a dream in which children were judged by the content of their character rather than the color of their skin. Left unspecified, of course, was how the content of their character was to be ascertained once the false lens of racism was cast aside. Although hardly legitimate heirs to Dr. King, the new moralizers can claim that their goal

reformatory institutions in the nineteenth century). Like their late twentieth-century counterparts, the early reformers also designed programs whose capacity was grossly insufficient to meet the scope of the problem they faced. When society found altruistic initiatives falling badly short, the emphasis in moral discourse shifted from what society should do to aid presumed innocents at its margins to condemnation of those marginal members for their supposed moral failings.

156. Robert Rector \& William F. Lauber, Heritage Found., America's Failed $\$ 5.4$ Trillion War on Poverty (1995) [hereinafter Rector \& Lauber, War on Poverty].

157. For example, because breast feeding often is good for infants' health and less expensive than buying infant formula, Congress required agencies administering the Special Supplemental Nutrition Program for Women, Infants, and Children (WIC) to engage in breast-feeding promotion activities. Because voting has civic importance, Congress also required these agencies to seek to register participants to vote (even though most likely have contact with other agencies covered by the "motor voter" law). As these and other theoretically meritorious mandates accumulated but administrative funding was left unchanged, some agencies complained that their efforts to provide nutrition education-a core function of the program that is an essential part of its justificationsuffered, opening the program to attack. See Douglas J. Besharov \& Peter Germanis, Rethinking WIC: An Evaluation of the Women, Infants, and Children Program 14-16 (2001) (criticizing the effectiveness of WIC's nutrition education).

To be sure, Franklin Roosevelt rallied the nation in his first presidential campaign by insisting that " $[t]$ he country needs . . . and . . . demands bold, persistent experimentation .... It is common sense to take a method and try it. If it fails try another. But above all, try something." Trattner, supra note 9 , at 279 . A principle that is workable when the nation faces a single, almost universally acknowledged problem such as the Great Depression does not translate well to a plethora of social problems emerging into the public consciousness more or less simultaneously, each helping to prevent the others from mobilizing a focused public response. 
is to get on with the business of judging people by the content of their character. Indeed, they have been able to foment and tap white anger over affirmative action to claim that liberals have reneged on their promise to replace racist value judgments with a true meritocracy. ${ }^{158}$

Liberals also may have helped reassure the public about the reliability, and hence the legitimacy, of moral judgments of blameworthiness by exaggerating the importance and accomplishments of the Due Process Revolution. A major concern about moralizing judgments throughout history has been the difficulty of arriving at the right answer. If, however, the Due Process Clause is now ensuring fair and reliable procedures, liberals have more trouble maintaining that innocents will suffer from erroneous findings of fault.

The liberals' habit of enacting expressive spending and regulatory programs has provided a precedent for the new moralizers to do the same. To be sure, the new moralizers likely would have adapted the legislative process to serve their expressive goals even if the liberals had not. Liberals' earlier misadventures with expressive policymaking, however, undermined their credibility in criticizing new moralizers' following suit. And while liberals' expressive legislation typically has been just symbolism, the new moralizers have perfected the art of camouflaging highly substantive legislation as expressive initiatives. Thus, while liberals' symbolic initiatives have often taken the form of establishing or expanding a program dependent on unreliable annual discretionary appropriations, the new moralizers have made their symbolic points through massive tax cuts that will starve the federal government of resources for decades to come. ${ }^{159}$ Liberals planted snapdragons; the new moralizers are planting sequoias.

158. See, e.g., Robert Woodson \& Dr. William J. Bennett, Heritage Found., The Conservative Virtues of Dr. Martin Luther King (Nov. 5, 1993), available at http://www.her itage.org/Research/AmericanFoundingandHistory/HL481.cfm (on file with the Columbia Law Review) (arguing that not only did Dr. King advocate a formally color blind society, but that society today is even further away from that goal than it was in Dr. King's time).

159. The Balanced Budget Act of 1997 provides a striking example of the different approaches of liberals and conservatives. Conservatives sought permanent tax reductions; liberals and the Clinton Administration sought funding for welfare-to-work programs, Medicaid expansion, restoration of some of PRWORA's cuts in immigrants' eligibility for public benefits, and other human services. Neither could enact legislation without the other. The final bill included several modest human services initiatives that President Clinton and congressional Democrats hailed as great victories. All, however, were designed to expire or shrink after the first few years. More importantly, all of those initiatives combined cost less than just one of the several major tax cuts in the legislation. Liberals dominated the short-term sound bites; conservatives dominated the shaping of the long-term fiscal agenda. See Robert Greenstein, Ctr. on Budget and Policy Priorities, Looking at the Details of the New Budget Legislation: Social Program Initiatives Decline Over Time While Upper-Income Tax Cuts Grow (Aug. 12, 1997), available at http://www. cbpp.org/812bud.htm (on file with the Columbia Law Review). Seven years earlier, the Democratic majority in Congress had been in a similar standoff with the first President Bush. The result at that time, although not quite so lopsided, gave liberals some modest tax increases and a package of social initiatives, but paired those measures with cbanges in 
Liberals' inability to resist political temptation also has reinforced the new moralizers' efforts to refocus public policy dialogue on individuals' morality. Although Senator Trent Lott's fall from the Senate leadership no doubt delighted many Democrats whom he had outmaneuvered for years, the message this sent was highly ambiguous. Demands for his ouster obviously were intended to underline the importance of civil rights and the offensiveness of praising Senator Strom Thurmond's racist presidential campaign. But the episode could just as easily be read as suggesting that racism, while serious, is largely a problem of isolated individuals' flawed morality. Lott was replaced as majority leader by a senator with a similar voting record and program; the impact of that program on people of color received little attention. Viewing racism as an individualized rather than societal problem, with individual racists identifiable only by outlandish statements such as Lott's, could encourage people to believe that the problem of minority hiring and college admissions could be addressed by purging admissions and personnel offices of individuals that publicly espouse racism rather than through affirmative action. Advocates of redressing broad social patterns of inequality even where intentional discrimination cannot be proven ${ }^{160}$ muddle their message by placing such emphasis on individuals' expressions of backwards racial views.

Conversely, liberals' conspicuous passivity in the face of behavior much of the public found offensive helped the new moralizers make their broader case that society has become too permissive. In this regard, perhaps the single greatest contributor to the new moralizers' success has been former President Bill Clinton. In his sexual involvements and subsequent dissembling, ${ }^{161}$ he provided a highly visible example of indisputably immoral behavior. The campaign to impeach him forced liberals to defend him and made them appear indifferent to morality when they

the federal budget process that effectively blocked most future expansions of entitlement programs and imposed ever-tightening caps on discretionary appropriations. These caps led to the gradual strangulation of low-income housing and many other nonentitlement programs. See Budget Enforcement Act of $1990 \$ \S 13111,13204-13207$, Pub. L. No. 101508 , 104 Stat. 1388-573, 1388-602 to $1388-607,1388-616$ to $1388-619$ (codified as amended in several titles of the U.S. Code, with the crucial budget process provisions in scattered sections of 2 U.S.C. and 31 U.S.C.) (reducing real discretionary spending limits over time). But see Robert Greenstein \& Paul Leonard, Ctr. on Budget and Policy Priorities, One Step Forward: The Deficit Reduction Package of 1990 passim (1990) (celebrating the shortterm fiscal results of the agreement while downplaying the long-term implications of the budget process changes). Arguably one of the great political injustices of modern budgetary politics was Republican conservatives' pillorying of President Bush for negotiating this deal, which did so much to advance their long-term agenda.

160. See, e.g., Washington v. Davis, 426 U.S. 229, 240-42 (1976) (holding that proof of discriminatory intent is required to prevail on equal protection challenge to facially neutral employment policy).

161. The common characterization of his misstatements as involving only personal matters is in fact too generous to the former president: His dissembling about his sexual activities came in the context of a suit for sexual harassment, which, whatever its motivation, is not a personal matter. 
argued against the new moralizers' proliferation of character tests. ${ }^{162} \mathrm{Be}-$ yond debilitating liberals' credibility on moral issues, Clinton provided more direct help to the new moralizers: For political advantage, he signed important pieces of legislation that accomplished their agenda, including CWAAA, the Defense of Marriage Act, AEDPA, PLRA, PRWORA, IIRIRA, and ASFA. This made it extremely difficult for liberals to contest the new moralizers without repudiating the first Democratic president elected to two terms since Franklin Roosevelt. The fact that Clinton defined himself as a policy technician or "wonk"-and that his supporters' enthusiasm clearly springs from this characteristic-provided the perfect demonstration of the moral inadequacy of technical approaches to policy formulation on which liberals long have relied.

Finally, progressives have undermined their longstanding tacit coalition with business interests to reduce the incidence of morality tests. The antiglobalization movement has suggested that, rather than being satisfied with relatively efficient transfer payments, a significant segment of progressives wants to impose populist restrictions on business that are likely to interfere with the ability to consolidate and compete. It should not be surprising, then, that some economic conservatives have made a common cause with the new moralizers despite the potential for more costly and inefficient adjudications of personal morality.

\section{B. Reconciling the New Moralizers and Economic Conservatives}

In discussing public welfare policy, the Heritage Foundation's Robert Rector calls for a shift in attention from "economic poverty" to "moral poverty." This shift in focus from the economic to the moral pervades the agenda of the new moralizers. In some respects, then, the rise of the new moralizers is the story of a remarkable role reversal by the conservative movement. After decades of economic conservatives berating liberals for substituting sentiment for rigor, the new moralizers adopted an approach to public policy that relies on assumptions about human nature fundamentally at odds with those of the law and economics school. Liberals, in turn, have received a nasty surprise: Just as many liberals were adopting the more rigorous, economically sophisticated mode of analysis that economic conservatives have long have been pressing on them, this large faction in the conservative movement lost interest.

Many observers have had difficulty recognizing the full contours of this agenda because in some important respects it represents a radical reversal of traditional conservative positions. The law and economics school that had dominated conservative thinking until recently emphasized economic factors as the key motivation for human behavior:

162. His lies about his sexual behavior also helped lower the public's expectations and give his successor far more range with which to advance dubious arguments for strategic tax cuts, the suppression of civil liberties, and military adventures. 
Economics ... explores and tests the implications of assuming that man is a rational maximizer of his ends in life, his satisfactions-what we shall call his "self interest." . . . 1t is implicit in this definition of man as a rational maximizer of his self interest that people respond to incentives-that if a person's surroundings change in such a way that he could increase his satisfactions by altering his behavior, he will do so. ${ }^{163}$

The new moralizers, by contrast, largely ignore incentives and instead see a wide range of human decisions as the product of moral character. These visions can be difficult to reconcile. ${ }^{164}$ Conversely, many of the liberal positions the new moralizers have opposed in fact depend on economic incentives and, but for their outcomes, could well be identified with the law and economics school.

More generally, the new moralizers offer a very different role for government. For the most part, the traditional law and economics school favors limited government and, when government does act, a clear, practical goal for its interventions. ${ }^{165}$ The role of government that the new moralizers pursue is neither limited nor necessarily practical. In numerous fields they ask the government to intervene in matters that could be handled by private actors-if not in the actual marketplace then in the marketplace of ideas. Many of the roles they would have the government take are far more expressive than practical. For example, despite evidence that needle exchange programs reduce the spread of HIV and other blood-borne illnesses-an impact with an obvious economic explanation in terms of altered incentives for substance-abusers-the new moralizers oppose these interventions because they appear to express tolerance of drug abuse. Some states are moving to deny drivers' licenses to undocumented immigrants-an action that is most unlikely to affect these immigrants' decisions to come to or stay in this country, or even to drive, but that does effectively deny the state the opportunity to screen out unsafe undocumented immigrant drivers. Similarly, the new moralizers have aggressively sought a role for the government in promoting marriage and premarital abstinence even though they lack much of a concept of how the government could effectively influence those intensely personal decisions.

\section{Richard A. Posner, Economic Analysis of Law 3-4 (2d ed. 1977).}

164. Presumably the response would be that bad moral character gives people socially objectionable ends or satisfactions. Yet many motivations the new moralizers attack-for example, welfare recipients' supposed preference for leisure over work or debtors' supposed strong desire for consumption-are wholly familiar to economic analysis. The choice to categorize these as moral wrongs rather than as forms of economic behavior to be addressed by adjusting economic incentives therefore needs to be explained in terms of ideology.

165. Thus, for example, the law and economics school dismisses minimum wage legislation as an expression of social concern for the wellbeing of low-skill workers and focuses on that legislation's practical effects, which it would find to be negative. 
In this way, new moralizers can escape the political liability for failed programs that has dogged liberals. New moralizers point to the continued existence of poverty as conclusive evidence of the "failure" of the "War on Poverty." "66 Liberals, with a practical and empirical orientation perhaps born of long battles with law and economics conservatives, have been reluctant to offer expressive justifications. Most have not, for example, argued that severe poverty in a nation this wealthy is so morally unacceptable that society has a duty to commit significant resources to ameliorating it even if its complete eradication is unattainable. Yet the war on drugs is justified in exactly the same terms despite its manifest failure. The massive 200I tax cut that failed to spur the promised economic growth similarly is justified as morally right for giving taxpayers back "their money" whatever its practical results may be. Presumably, we can expect similar justifications for marriage promotion initiatives in a few years.

\section{The Collapse of the Technocratic Middle}

The highly technical mode of argument liberals came to adopt in the I970s after the New Left's decline depended on several assumptions. The first and most obvious, addressed above, was a broad consensus on a basic set of social values such as prevention of destitution among lowincome families, preservation of the environment, a secure retirement for the elderly, and protecting consumers from the worst deceptive practices. ${ }^{167}$ The erosion of this consensus both contributed to and was hastened by the rise of the new moralizers. Other conditions necessary for a political system to resolve social policy disputes through technical debate also have begun to collapse.

First, technical debates only work if all participants are under some pressure to limit their substantive assertions to those that can be reasonably supported by plausible data. This does not mean that twisted or misused data will never see the light of day. In this system, however, advocates regularly advancing factually unfounded arguments ultimately are shunned by their own ideological allies as well as their foes. Pseudoscientific theories of white racial superiority did not die out in the I960s, but mainstream conservatives ignored their proponents with the same consistency that liberals did. A variety of thinly supported conspiracy theories on both the left and right have brought a similar isolation to their steadfast proponents. The process of isolating those who misuse data, however, appears to be breaking down with respect to many of the contentions of the new moralizers. ${ }^{168}$ Authors of data analyses that have

166. See Rector \& Lauber, War on Poverty, supra note 156.

167. See supra Part I.C.

168. Alternatively, the basis on which ideas are designated outside the mainstream has shifted from the analytical to the political. With both major parties heavily implicated in the 1996 welfare law and eager to vindicate their support of it, critical perspectives have become marginalized. Journalists of a wide range of perspectives treat PRWORA's success 
been repeatedly discredited retain important roles in policy formulation. ${ }^{169}$ Their continued success encourages others to follow suit. With the vast majority of the public-and, indeed, senior policymakers-lacking the time, skills, or interest to assess the credibility of competing claims on highly technical issues, these debates almost automatically become draws. Society then must make its decisions on some other basis.

Second, policymaking based on technical arguments requires the news media routinely to present the arguments in enough detail to affect the opinions of a significant number of people. Detailed analyses of complex policy debates, however, do not generate ratings or sell many newspapers and magazines. Moreover, if a journalist writes a news analysis finding that one side has been misleading the public, the public officials sympathetic to that side may be disinclined to provide the kind of access the journalist needs to get the kinds of stories that do have commercial value. As more and more people have come to get their news from outlets owned by companies whose primary focus is not journalism, the capacity to debate technical issues to any meaningful conclusion has evaporated. ${ }^{170}$

as a proven fact; those continuing to assert that it was ill advised get little coverage despite a complex research record that proves extensive evidence of both positive and negative consequences.

169. See Jason DeParle, Homeless in Hot Tubs: Want to Wipe Out Poverty? Give a Conservative a Calculator, Wash. Monthly, JulyAug. 1991, at 51 (analyzing Heritage Foundation's attempts to deny severity of poverty and noting, for example, that Heritage's claims that 22,000 poor families have jacuzzis or heated swimming pools were extrapolated from four observations in a survey, using methods the survey's manager called "statistical malpractice"); compare e.g., Heritage Found., America's Poor, supra note 46 (quoting Rector as asserting that the Census Bureau failed to report $\$ 11,120$ per poor family by failing to count in-kind programs), and Rector \& Lauber, War on Poverty, supra note 156 (asserting that the War on Poverty has spent $\$ 5.4$ trillion to little effect), with Robert Greenstein, Ctr. on Budget \& Policy Priorities, Attempts to Dismiss the Census Poverty Data (1993) (noting that Rector's \$11,120 figure includes programs' administrative overhead, programs that pave streets, and benefits provided to people well above the poverty line), and Sharon Parrott, Ctr. on Budget \& Policy Priorities, How Much Do We Spend on "Welfare"? (1995) (finding that Rector's figures treat as "welfare" substantial amounts of spending in such non-means-tested programs as Medicare). Yet Rector was the principal noncongressional author of PRWORA and continues to be quoted extensively in the media on these very issues. Hilary Stout, GOP's Welfare Stance Owes a Lot to Prodding from Robert Rector: The Policy Analyst Argues Current System Promotes Dependency, Illegitimacy, Wall St. J., Jan. 23, 1995, at A1 (describing Rector's pivotal influence despite the discomfort of some other conservatives with his methods).

170. See, e.g., In the Matter of 2002 Biennial Regulatory Review-Review of the Commission's Broadcast Ownership Rules and Other Rules Adopted Pursuant to Section 202 of the Telecommunications Act of 1996, 18 F.C.C. 13,620, 13,951-55 (July 2, 2003) (Copps, Commissioner, dissenting) (describing consolidation in the industry resulting in many broadcasters being under large parent companies); David D. Kirkpatrick, New Rules Give Big Media Chance to Get Even Bigger, N.Y. Times, June 3, 2003, at C1 (describing the way FCC regulations will allow "media leviathans" to further consolidate control at expense of smaller local broadcasters). 
Third, and related, the definition of balance that many journalists apply has subtly changed. Instead of seeking to present the facts as accurately as possible and then offering a balanced presentation of normative perspectives on those facts, journalists simply present the assertions of both sides, including both fact and opinion, with little effort to sort out the factual disputes between the opposing sides. ${ }^{171}$ Thus, when the Administration claimed that the "average taxpayer" will receive a tax cut of a certain amount, many news outlets reported that assertion alongside liberals' assertion that the typical taxpayer would receive far less, but made no attempt to explain that the Administration computed its "average" by combining many middle-income taxpayers who would receive modest amounts with very affluent taxpayers getting the lion's share of the tax cuts. Most of the public has no idea how to interpret these apparently inconsistent claims and forms opinions of the underlying policy issue on some other basis: ideological leanings, self-interest, or something else. The technical debate has become increasingly irrelevant.

Fourth, affinity for the value of journalistic balance, however defined, has eroded. Conservative news outlets increasingly content themselves with presenting only the new moralizers' narrative on important issues. ${ }^{172}$ Were this policy explicitly acknowledged, voters might make an effort to balance their news intake. As it stands, however, journalists' failure to present the other side of an issue may be interpreted as meaning that there is no credible opposing viewpoint. At best, if voters see a balance of liberal and conservative opinions in some outlets and a consistently conservative drumbeat in others, they may not unreasonably conclude that most of meritorious arguments on the subject are conservative.

Finally, as the new moralizers who have seized the leadership of the Republican Party have succeeded in increasing the stringency of party discipline, the number of policymakers whose decisions on important issues genuinely rest on technical policy debates has declined. Some of those who might previously have been swayed have swallowed their reservations and hewed to the new party line. Others have left public office. ${ }^{173}$

171. Conservative pressure on the news media to avoid "instant analysis" of their factual assertions can be traced back at least to Vice President Agnew. See, e.g., Meredith C. Hightower, Beyond Lights and Wires in a Box: Ensuring the Existence of Public Television, 3 J.L. \& Poly 133, 152-53 n.72 (1994) (summarizing the Nixon Administration's efforts to obtain more favorable coverage by criticizing the news media for bias).

172. See Paul Krugman, Reading the Script, N.Y. Times, Aug. 3, 2004, at A19; Paul Krugman, To Tell the Truth, N.Y. Times, May 28, 2004, at A21.

173. For example, the critics of the Bush Administration's massive tax cuts have included former Republican members of Congress and cabinet officers working with the Concord Coalition. Their impact on current members, however, has been limited: A few have expressed reservations about the massive tax cuts and sought concessions in the nominal cost of those cuts. Not enough, however, felt strongly enough to vote "no" after the Republican leadership inserted artificial expiration dates. Assuming, as the Republican leadership avowedly does, that these tax cuts become permanent, the resulting 
Still others have shifted to become predictably liberal. ${ }^{174}$ This latter group (and others) may still insist on technically sound policies, but its members no longer hold the balance of power on most major decisions.

\section{The Populist Appeal of the New Moralizers}

Although they represent a sharp break with some earlier versions of conservative thought, the new moralizers have a great deal to offer many different conservative constituencies. Much of their success depends upon their ability to unite these quite disparate elements. Here again, their campaign to increase the prominence of tests of moral blameworthiness are key.

Most obviously, the new moralizers offer economic conservatives fresh, readily comprehensible arguments for limited government. They legitimize efforts to reduce taxation and to replace broad-based regulation of industry. This certainly made allying with the new moralizers more appealing than continuing to work with liberals to reduce regulations' administrative burdens.

The new moralizers also neatly finesse the problem of race by presenting a sort of mirror for each individual's assumptions about other people's morality. If rewards are being distributed on the basis of individuals' supposed moral probity, recalcitrant racists will assume that African Americans, Latinos, and other minorities will do poorly; mainstream conservatives will assume that they have constructed a nonracial meritocracy.

More broadly, the new moralizers offer a tangible, seemingly intelligible response to social dislocation for those who have difficulty following complex arguments about economic efficiency or the behavior of institutions. Assuming the listener does not regard himself or herself as immoral, a system that ties rewards to virtue poses risks only to others.

Comparing the fairness of the tests of morality the new moralizers imposed on politically weak groups with those established for elites is difficult because the contexts in which they are being applied are so different: What is required for a single parent with weak employment skills to avoid receiving cash assistance for five years, for example, can hardly be compared with what is required for an executive to present a fair account-

revenue losses approach or exceed those that the Administration originally proposed, before its cosmetic concessions.

174. Senator James Jeffords's defection from the Republican caucus, and Senator Lincoln Chafee's open contemplation of a similar move should Senate control ever depend upon his vote, are but the most public evidence of a realignment of socially moderate economic conservatives with the Democrats. To be sure, a Republican Party whose platform currently reflects much of the new moralizers' agenda bas won over enough additional rural areas to take power, often with support from like-minded Democrats such as Senator Zell Miller. On the other hand, suburban voters, at least outside of the South, have moved in the opposite direction. See, e.g., Charles E. Cook, Jr., How Does 2000 Stack Up?, 24 Wash. Q. 213, 215-16 (Spring 2001); Seth C. McKee \& Daron R. Shaw, Suburban Voting in Presidential Elections, 33 Presidential Stud. Q. 125 (2003). 
ing of her or bis company's financial difficulties. The absolute fairness of many of these measures also is difficult for most middle-income voters to judge, as few have experience either with the conflicting demands lowincome single parents face or with the pressures on a conflicted corporate executive. The validity of the moral tests are only likely to trouble middle-income voters on those rare occasions when they happen to have had experience engaging in practices the tests will punish. Thus, proposals to substitute market investments for some or all of Social Security benefits-and implicitly to punish those workers that invest poorly-foundered when millions of middle-income people's $401(\mathrm{k})$ retirement plans lost badly in the stock market skid accompanying the recession of 2001.175

In practice, the severity of the morality tests imposed on various groups varies considerably. Most obviously, some groups (such as welfare recipients or parents whose children are in foster care for fifteen months) are presumed to be blameworthy without evidence of intent; others, such as corporate executives or police officers, enjoy substantial presumptions of regularity. In addition, some groups are only required to behave ethically in roles they have chosen to perform while others are forced to make difficult choices: which managed-care plan or investment advisor to trust in the absence of much information, whether to place their children's well-being in the hands of a dubious day care provider or risk a welfare sanction for failing to work, etc. More broadly, determining the severity of moral tests based on assumptions about the virtue of those being judged is as corrupt as it is circular. Consciously or not, we tend to give virtual free passes to those who seem most like ourselves. This very feature, however, gives the new moralizers considerable popular appeal.

More broadly, the movement back toward a more moralistic approach to law and public policy should not come as a surprise. Basically content societies may be comfortable leaving the resolution of policy questions to a technocratic elite. Rapid economic and social change in recent years has displaced enough people, and left enough unresolved social tensions, that many predictably are interested in finding someone to blame and demanding higher moral standards. What is remarkable, however, is the vast imbalance between the effectiveness of new moralizers and liberals in adapting to and exploiting this receptivity to morally based arguments.

\section{E. Responding to the New Moralizers}

The changes the new moralizers have wrought in the way this country makes, enforces, and thinks about laws are profound. Their impact

175. See, e.g., Thomas Bray, Fallout Comes from Recession That Wasn't, Detroit News, Mar. 6, 2002, at 15A; Amy Goldstein, Bush Continues to Back Privatized Social Security, Wash. Post, July 25, 2002, at A6; Salim Muwakkil, Big Government's Embrace of the Comfort Zones, Chi. Trib., Oct. 8, 2001, § 1, at 19. 
will be felt far beyond any particular election cycle. No simple, effective defense is available to those troubled by the new moralizers' agenda; they must prepare to contest that agenda for a long time to come. Yet although no perfect inoculation is available, neither are liberals and traditional conservatives doomed to the kind of hapless defense that they have tended to offer to date. This Part offers some suggestions about how a more coherent response might be constructed.

At the outset, opponents of the new moralizers should recognize that they cannot succeed through dogged pursuit of technical arguments that assume a now-demolished consensus on the goals of social policy. The new moralizers will dispute every significant point their opponents raise, and far too few policymakers, journalists, and members of the public will have the time, interest, or skills to discern which side is correct. "Work requirements" sound appealing; appreciating the lack of ability or opportunity to work requires much closer study. Resolving child welfare cases within fifteen months sounds commendable; the lack of services to help parents provide better homes, or the bleak prospects for adoption that await many of these children, are far less intuitive. Appreciating the severity of the restrictions CWAAA, AEDPA, PLRA, PRWORA, and IIRIRA impose on substance abusers, immigrants, and prisoners requires more legal sophistication and empathy than most people can muster. The new moralizers have polarized public policy debates to the point where few impartial third parties are available to arbitrate these disputes effectively. More fundamentally, identifying a technically sound road does little good if there is no agreement about the destination.

Neither will ad hoc attacks on the rectitude of particular new moralizer leaders or groups fundamentally undermine the new moralizers' power to steer social policy discourse. This movement is far bigger than any one or few individuals who might be toppled in an election or scandal. ${ }^{176}$

Responding effectively to the new moralizers requires several distinct changes in liberals' and traditional conservatives' approaches to political discourse. First, this effort requires reasserting the case Justice Holmes made more than a century ago, that law and morality should have different roles in a free society and that conflating the two can produce dan-

176. Both of the new moralizers' top leaders in the 104th Congress that brought this agenda to the fore-Speaker Newt Gingrich and Senate Majority Leader Trent Lott-have fallen in embarrassment. (Senator Bob Dole, a more pragmatic figure, was majority leader at the beginning of the 104th Congress but stepped down to run for president before PRWORA, IIRIRA, and some other important pieces of legislation passed.) Yet the movement has grown even stronger with more reassuring leaders before the television cameras. Any chance that the public might have learned useful lessons about the relationship between money and politics or about racial sensitivity was lost in the Democrats' gleeful partisan exploitation of these scandals. Particularly in light of the new moralizers' relentless emphasis on judging individuals' virtue, the public is most unlikely to draw any inferences beyond the particular politicians involved. 
gers. ${ }^{177}$ This is not to say that moral considerations have no role in guiding the law: For liberals and economic conservatives to retreat into purely technical arguments would be disastrous. But they must be prepared to argue that some social problems, even serious ones, may not be immediately susceptible to a legislated response. To give credibility to this effort, liberals must curtail their expressive use of legislation. As long as liberals retain their affinity for symbolic actions, they will be ill equipped to argue against appealing new moralizer initiatives as unlikely to achieve their stated purposes.

Second, the response to the new moralizers must be framed in terms that appeal across party lines. Tying the fate of liberal policies to that of the Democratic Party obviously is tempting: Most liberals are Democrats, and the new moralizers are led by extremely partisan Republicans. Yet in our system, both parties are likely to alternate in power. Values do not become securely embraced in public policy unless and until they find some measure of acceptance within both political parties. ${ }^{178}$ The new moralizers' rhetoric and legislation is easier to launch than to cabin: If every Republican victory means another new moralizer salvo, the longterm effects will be severe. Moreover, even liberal Democratic leaders' loyalty to their own short-term electoral interests generally will supersede any commitment to resist or repair the results of new moralizers' initiatives. ${ }^{179}$

177. Oliver Wendell Holmes, The Path of the Law, 10 Harv. L. Rev. 457, 460 (1897) ("Nothing but confusion of thought can result from assuming that the rights of man in a moral sense are equally rights in the sense of the Constitution and the law."). Because the prohlematic equation of law and morality here is rhetorical and political rather than jurisprudential, this obviously does not require the new moralizers' critics to navigate the shoals of natural law and positivism. See supra note 2 and accompanying text (noting that the moral arguments at issue here are the work of moral entrepreneurs, not systematic ethicists). As the new moralizers have proven, however, politicians and voters can fall victim to the same sort of fallacious reasoning that Holmes warned judges to avoid.

178. Bipartisan support assures a continuing public role in environmental protection even as the parties battle over bow that responsibility should be discharged. The distribution of our foreign assistance budget remains relatively stable over time because most of it reflects moral obligations both parties have accepted. Had the condemnation of Senator Joseph McCarthy passed on a party-line vote, he would have remained a dangerous force in American politics.

179. President Clinton, through his "triangulation" strategy, deliberately sought to embarrass and undercut Democratic liberals to gain personal political advantage. When this strategy, and his mishandling of the healthcare reform debate, contributed to the Democrats' loss of Congress in 1994, he made little attempt to moderate, much less block, much of the new moralizers' legislative agenda, such as AEDPA, PLRA, CWAAA, PRWORA, IIRIRA, and AFSA. He did veto one welfare bill while a massive blizzard in January 1996 shut down much of the Washington news media, thus limiting critical coverage, but the bill he ultimately signed was not dramatically more moderate-indeed, in some areas, such as its treatment of immigrants and cuts to the food stamp program, it was even more draconian. (To his credit, however, he did veto the bankruptcy legislation that would have redistributed vast sums from debtors to credit card companies under the guise of promoting personal responsibility. And many of his lower-profile actions did indeed help 
Third and most importantly, liberals and traditional conservatives need to rediscover the ability to make moral arguments. This entails three components, corresponding to the three basic moral questions that shape public policy identified at the outset of this Essay. ${ }^{180}$ They should promote a vision of morality that imposes duties on society as well as individuals. In essence, they must bring back to the fore the question of what society should do for the unfortunate. In addition, they must make the case for reducing the number and importance of moral judgments of individuals in public policy. As we have seen, the rigor of these judgments will inevitably vary sharply depending on who is being judged, with much more exacting standards applied to individuals in politically weak and unpopular groups. The more public policy seeks to impose individual morality tests, the more inequities are likely to result. Finally, they must make a case for proportionality in imposing sanctions on those found to have strayed from virtue. In part, this requires separating the issue of sanctions from the issue of whether a moral test should be imposed in the first place: establishing that one can seek to moderate penalties for problematic conduct without approving of that conduct. It also requires eroding the binary vision of individual morality that animates many of the new tests of personal virtue, reminding the public that most people are neither entirely good nor entirely evil.

\section{CONCLUSION}

The new moralizers are ascendant, but they are not invincible. The humane instincts that brought this country progress in civil rights, environmental quality, workplace safety, consumer protection, and the amelioration of poverty have not vanished, al though they are shielded by a thicker layer of suspicion and cynicism than before. The goal of liberals and traditional conservatives need not and should not be to vanquish moral concerns from policy debates and return the law to an amoral pursuit of efficiency. Instead, it ought to be to offer a more compassionate and constructive vision of how morality should help shape the law. With determination and discipline, this can, and must, be done.

some of the targets of the new moralizers, particularly some low-income people and immigrants.)

180. See supra Part I.A. 